Table 2 Number of papers contributed from various countries

\begin{tabular}{l|r}
\hline 国名 & 論文数 + (招待論文数) \\
\hline 日 本 & $44+(2)$ \\
米 国 & $25+(2)$ \\
英 国 & $17+(1)$ \\
ドイッ & $15+(1)$ \\
オランダ & $5+(1)$ \\
フランス & $4+(1)$ \\
スイス & 2 \\
イタリヤ & 1 \\
ブラジル & 1 \\
ノルウェー & 1 \\
ベルギー & 1 \\
中 国 & 1 \\
\hline
\end{tabular}

寄与を表 2 にまとめてみた。論文数がその国の 光通信技術開発状況を端的に表わしていると思 われる。日本からの論文寄与数が断然群を抜い ており，全体の約 4 割を占めていた。種々の国 からの発表があったが、中でも中国からの発表 があり注目をあつめた。（あとで中国の参加者 から直接聞いた話であるが, 中国ではすでに半 導体レーザー, ファイバを製造しており, 光通 信実験が北京市で進行中とのことである。）

本会議の報告書を作成するにあたり，発表内 容が非常に多岐に旦るので，正確を期すために， 四人で分担することにし，表 1 に示すように，

「光源と光検出器」関係を高宮が，「ファイバ」 関媇を稲田が，「光通信システム」関係を石尾 が，そして「光集積回路」関係を西原がそれぞ れ分担し，全体の体裁を西原がと>のえた。

\section{2. 講演内容}

\section{$2.1 「$ 光源と光検出器」関係}

光源および検出器に関しては24件の発表が行 なわれた。表 $3 ， 4 ， 5$ にそれぞれの概要と発 表研究所を示す。

今回の会議で大きくクローズアップされたの は長波長化への動きとマルチモードレーザーの
評価であった。長波長化に関しては東工大末松 教授による招待講演を始めとして日本勢の 1.3 $\mu \mathrm{m}$ や $1.5 \mu \mathrm{m}$ レーザーやホトダイオードおよび LED 開発の勢いが際立っていた。また，Bell 研究所による $1.5 \mu \mathrm{m}$ シングルモードレーザー, ミュンヘン大学による $1.26 \mu \mathrm{m} \mathrm{LED} の$ 発表な どがあった。一方, 反射雑音やスペックル雑音 の観点からシングルモードレーザーよりマルチ モードレーザーが良いとの発表が英独日合わせ て 4 件あった。これらはシングルモードレーザ 一があらゆる点で良いとする従来の大勢に冷水 を浴びせるものであった。上記雑音を防止する オーソドックスな方法として近年では光アイソ レータやシングルモードファイバの利用が図ら れている。しかしながら，これらの実用化の見 通しが得られる迄の間, アナログ通信分野では シングルモードレーザーは冷水を浴び続ける可 能性もある。

\section{2「ファイバ」関係}

光ファイバ・ケーブルに関する発表論文件数 はポストデッドライン論文も含めるとほぼ50件 あり，今学会の総発表論文数 127 件のほぼ $40 \%$ に相当した。なお50件中17件が日本からであり， 日本の活躍が目立った。

ファイバ関係の論文は, 製造, ケーブル，接 続, 機械特性, 伝送特性, 測定, 理論に分け発 表された。

ファイバの製造に関しては, VAD (vapour phase axial deposition) と屈折率プロファイ ルに関するもの 2 件， 2 重ルッボ法で製造され たコンパウンドグラスファイバの特性および高 NA コンパウンドグラスファイバに関する報告 が 2 件, シングルモードファイバに関するもの 3 件, プラズマ法によるもの 2 件, 軍用ファイ バ 1 件, 紡系法やコーテング法によるもの 3 件 であった。VADに関しては当然ながら日本が独 壇場であり，第 1 回IOOC で発表された後の着 実な技術的進歩が報告された。コンパウンドグ ラスファイバに関しては英 Post Office が相 変らず頑張っており, 製造長 $230 \mathrm{~km}$ の損失が 
Table 3. Papers on laser diodes.

\begin{tabular}{|c|c|c|c|}
\hline & 容 & 研 究 所 & $\begin{array}{l}\text { 論 } \\
\text { 番 }\end{array}$ \\
\hline 1 & $\begin{array}{l}1.3 \mu m \text { 及び } 1.5 \mu m \text { 帯 In GaAs Pレーザの研究開発状況や性能, 寿命 } \\
\text { 等の現状の総括。 }\end{array}$ & 東工大 & 2.1 \\
\hline 2 & 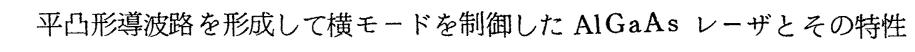 & 電 & 2.2 \\
\hline 3 & $\begin{array}{l}\text { LOC構造化によって埋込みへテロ形.AlGaAs：レーザの出力を増大し } \\
\text { た。非線形性も小さい。 }\end{array}$ & 立 & 2.3 \\
\hline 4 & $\begin{array}{l}\text { プロトンボンバードとZ n 選択拡散を併用してストラィプを形成し横モ } \\
\text { ード制御をしたAlGaAs レーザ。 }\end{array}$ & CNET (仁) & 2.4 \\
\hline 5 & $\begin{array}{l}\text { キンクがあるマルチモードレーザとC S P レーザの雑音を比較, C S P V } \\
\text {-ザが優れているてと, 及び反射光があるとC S P レーザも種々の雑音 を } \\
\text { 発生する。 }\end{array}$ & $\begin{array}{l}\text { Swis s Federal } \\
\text { Inst. of } \\
\text { Technol. }\end{array}$ & 2.5 \\
\hline 6 & $\begin{array}{l}\text { シングルモードレーザと縦マルチモードレーザの干渉距離を比較測定し， } \\
\text { 後者でモード杂隹音が小さくなると説明。 }\end{array}$ & S T L (英) & 4.2 \\
\hline 7 & $\begin{array}{l}\text { 縦マルチモードレーザの雑音特性と非線形性を評価し，モード杂隹音が小 } \\
\text { さいと主張。 }\end{array}$ & S T L (英) & 4.3 \\
\hline 8 & $\begin{array}{l}\text { 屈折率ガイドレーザとゲインガイドレーザの } \mathrm{S} / \mathrm{N} \text { を計算比較してゲイ } \\
\text { ンガイドレーザが有利と説明。 }\end{array}$ & A E G (独) & 4.4 \\
\hline 9 & $\begin{array}{l}\text { T J Sレーザの電子注入効率増大と製造プロセスの改善でシングルモー } \\
\text { ド発振上限温度が } 80^{\circ} \mathrm{C} \text { 上上になり寿命も } 10 \text { 時間になった。 }\end{array}$ & 菱 & 4.5 \\
\hline 10 & $\begin{array}{l}\text { アンチメルトバック層を形成して } 1.55 \mu \mathrm{m} \text { 室温 CW In GaAsPレーザ } \\
\text { を実現， } \mathrm{I}_{\mathrm{th}} \sim 150 \mathrm{~mA}, 1000 \text { 時間以上動作している。 }\end{array}$ & $\mathrm{K} \mathrm{D} \mathrm{D}$ & 16.1 \\
\hline 11 & $\begin{array}{l}\text { 結晶成長温度を下げることによって } 1.55 \mu m \text { 室温 CW In GaAsPレー } \\
\text { ザを実現。 }\end{array}$ & 研 & 16.2 \\
\hline 12 & 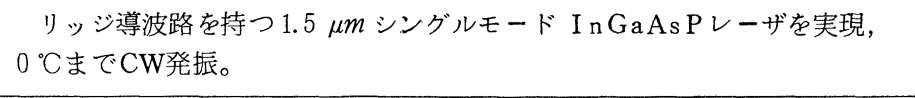 & $\mathrm{B}$ e 11 & 16.3 \\
\hline 13 & 導波路の上下に電流搾りを形成したCS Pレーザを開発。 & $\begin{array}{l}\text { California } \\
\text { Univ. }\end{array}$ & 16.6 \\
\hline 14 & 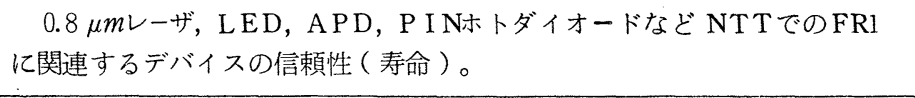 & 研 & 18.2 \\
\hline 15 & $\begin{array}{r}\text { 故障の時間的推移がログノーマルになる素子のバーンイン時間の最適化 } \\
\text { ( 理論 ) }\end{array}$ & B e 11 & 18.3 \\
\hline 16 & $\begin{array}{l}\text { 横シングルモードレーザの高調波歪のストライプ幅, 電流および周波数 } \\
\text { 依存性の理論と実験。 }\end{array}$ & 立 & 18.5 \\
\hline 17 & $\begin{array}{l}\text { 基板結晶に格子を形成することによって1回のエピ成長で } 1.3 \mu m \\
\text { In GaAsP のDFBレーザを試作。 }\end{array}$ & 立 & 18.6 \\
\hline
\end{tabular}


Table 4. Papers on LED.

\begin{tabular}{|c|c|c|c|}
\hline & 内 & 研 究 所 & $\begin{array}{ll}\text { 論 } & \text { 文 } \\
\text { 番 号 }\end{array}$ \\
\hline 1 & $\begin{array}{l}\text { InGaAsP LEDの発光面をレンズ状に成形してファイバとの結合効率 } \\
\text { を向上, ファイバ内パワー, } \mathrm{f}_{\mathrm{c}} \text {, 全パワー, 寿命を紹介。 }\end{array}$ & 富 士 通 & 4.6 \\
\hline 2 & $\begin{array}{l}1.2 \mathrm{GH}_{\mathrm{z}} \text { まで応答する }(-3 \mathrm{~dB}) 1.26 \mu m \text { の In Ga As P-LED 開 } \\
\text { 発した。出力は } 100 \mu \mathrm{w}_{\circ}\end{array}$ & $\begin{array}{l}\text { Universität } \\
\text { München }\end{array}$ & 16.4 \\
\hline 3 & $\begin{array}{l}\mathrm{GaAs}, \mathrm{AlGaAs}, \mathrm{InGaAsP}, \mathrm{InGaAs} \text { - LED の特性, 寿命等の総 } \\
\text { 合的解説 }\end{array}$ & Plessy & 23.2 \\
\hline 4 & $\begin{array}{l}\text { 集中定数的取扱いでLEDのスイッチング時間を求め，乙れと実験との } \\
\text { 対応からキャリヤの再結合寿命を求めた。 }\end{array}$ & $\begin{array}{l}\text { Swiss Federal } \\
\text { Inst. } \\
\text { of Technol. }\end{array}$ & 23.3 \\
\hline
\end{tabular}

Table 5. Papers on photo detectors.

\begin{tabular}{|c|c|c|c|}
\hline & 容 & 研 究 所 & $\begin{array}{l}\text { 論 } \\
\text { 番 } \\
\end{array}$ \\
\hline 1 & $\begin{array}{l}\text { リーチスルー形APDでチャネリングを利用したイオン注入を行な } \\
\text { い } \mathrm{k}_{\mathrm{eff}} \sim 0.08 \text { を得た。（増倍雑音低减） }\end{array}$ & Philips & 4.1 \\
\hline 2 & $\begin{array}{l}1.3 \mu \mathrm{m} \text { 用 InGaAs P ホトダイオードとその10素子アレイの特性並び } \\
\text { に1.6 } \mathrm{mm} \text { 用 InGaAs ホトダイオードの特性紹介。 }\end{array}$ & 三 菱 & 18.1 \\
\hline 3 & $\begin{array}{l}\text { APDにおけるバルク漏れ電流を誤り率と漏れ電流の関係式と誤り率の } \\
\text { 実測值から推定する。 }\end{array}$ & $\mathrm{S} \mathrm{T} \mathrm{L}$ & 23.5 \\
\hline 4 & $\begin{array}{l}\text { P I N ホトダイオードとFE.T を組合わせたハイブリッド受光アンプで } \\
160 \mathrm{Mbit} \text { のとき }-45 \mathrm{~dB} m \text { 入力で } 10^{-9} \text { の誤り率を得た。 }\end{array}$ & $\begin{array}{l}\text { P. O. } \\
\text { Research C. } \\
\quad(\mathrm{U} \cdot \mathrm{K} .)\end{array}$ & 13.4 \\
\hline
\end{tabular}

$3.5 \sim 5.5 \mathrm{~dB} / \mathrm{km}$ at $0.85 \mu \mathrm{m}$, 带域が 100 $900 \mathrm{MHz} . \mathrm{km}$ であった。MCVD (modified (hemical vapour deposition) 法に比べれば まだまだ劣るものの，よくここまで改善できた と誌われる。シングルモードファイバに関する 3 件はいずれも MCVD 法を使用し, 比較的厚 いクラッド層をいかにして作るかに関するもの であり，P，B，F等を用い，かつ $\mathrm{OH}$ 基を低減 させ，長波帯で $0.5 \mathrm{~dB} / \mathrm{km}$ 程度のものが得られ て执り，今や铰波長帯で $1 \mathrm{~dB} / \mathrm{km}$ 以下のシン グルモードファイバが容㺋に得られるようにな つた感じを得ける。フィリップス社拉よび英 $\mathrm{S}$

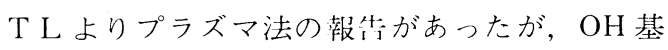
の低減には苦しんでいるようであった。
ケーブル化に関する铪文は紹待铪文も含め, わずか 5 件であったが，月本からはジェリ一人 ケーブル, ケーブル構造の最適没尌, 萡密度ケ ーブルの 3 件をしめ, 残り 1 件は Bell からの 海底用に設部製作されたシングルモードケープ ルに関するものであった。な掞ヨーロッパから の報年はなかった。

ファイバの接続に関しては，シングルモード

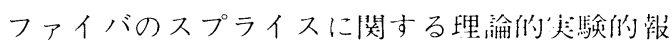
告，真空引き装置を使用したりリボン型ファイ バのスプライスの㙜験，その他光スイッチ 2 件, コネクタ 2 件, 結合器 2 件滗であった。

機械的搔度に関するものでは，ファイバにか かるストレス, すなわち伸びや絎みをパルス位 
播時間から測定し解折したもの，スクリーニン グテストによるファイバの劣化の実験に関する もの，ワイブル分布の取り扱い方に関するもの， テープ形ファイバのねじりによる強度劣化に関 するものなどいずれも実用上興味ある論文で, ファイバの強度に関する問題が毎年着実に解明 されていく感じを受けた。

伝送特性に関しては，シングルモードファイ バに関するものが紹待論文も含め 4 件も発表さ れたが，いずれも偏波特性に関するものであっ た。その他は，熱による屈折率プロファイルの 歪と帯域の問題, 二ュートロン照射による伝送 損失の増加, 低温における損失増加のメカ二ズ ムとその防止法, 高 $\mathrm{GeO}_{2}$ ファイバやVAD フ アイバであった。

ファイバの測定に関するものは 4 件中 3 件が 屈折率分布の測定も含め伝送帯域に関するもの で，残り 1 件がフォールトロケータに関するも のであった。なお，昨年多数発表されたバック スキャタによるファイバおよび接続部の測定法 は，接続セッションでコネクタの接続損失の測 定に関して 1 件発表されたのみであった。

理論に関してはシングルモードファイバの各 種パラメータの決定法, 屈折率プロファイルか ら伝送帯域を求める方法，ランダムベンドによ るシングルモードおよびグレーデッドインデッ クスファイバの損失増加，グレーデッドインデ ックスファイバの伝送帯域の長尺特性など，い ずれも非常に実際的な問題が発表された。

以上，今回の学会の特徴としては，ファイバ 部門に関し新しい製造方法の発表がなかったこ と，ただし製造方法の改善等着実な成果を上げ ると共に実用的な報告が目立ったことなどであ る。なおシングルモードファイバに関しては, 理論，製造法，ケーブル，接続等多くのセッシ ヨンで数多く発表されたが，今後光ファイバの 研究が長波長帯へ移向していくと同時にそれら の検討はますます活発になるものと思われる。

$2.3 「$ 光通信システム」関係

波長分割多重 (Wavelength-Division-
Multiplexing）伝送はフアイバの広い波長域に わたる低損失性を利用して，波長の異なる複数 の光信号を一本のファイバで伝送するための技 術であり，日本が先行している分野の一つであ る。Integrated Optics and Wavelength Multiplexing I のセッションでは日本から石 尾（電電公社横須賀通研）が “W avelengthDevision-Multiplexing Transmission Technology” と題する招待論文の講演を行な い，波長分割多重伝送のKey Device である 光分波器の現状, 設計法, 適用領域ならびに実 験システム例について述べた。波長分割多重伝 送については，他に 2 件の発表があり，1件は

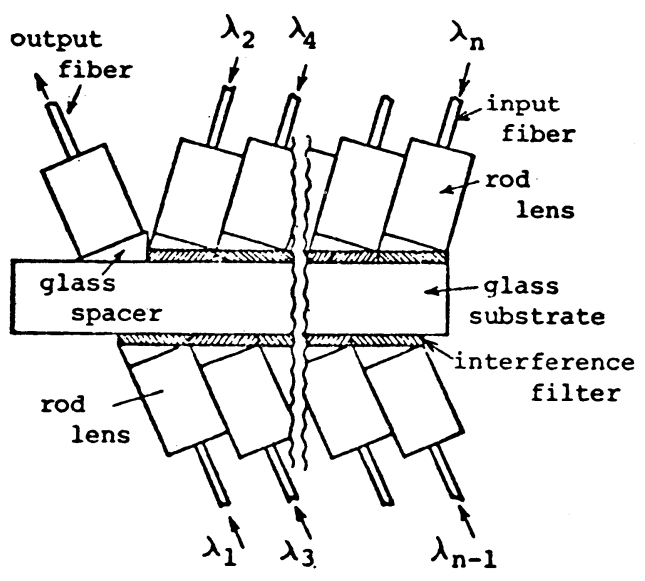

Fig. 1. Wavelength multiplexer of multiplereflection type

図 1 に示すようにガラス基板を誘電体多層膜フ イルタでサンドイッチし，膜フィルタ間をZigZag に反射を繰り返しながら分波を行なう形 式の光分波器の発表であり，新しいレンズ構造 在用いて送受光分波系の損失として $3 \mathrm{~dB}$ 以下 を実現している（横須賀通研）。他の 1 件はB $\mathrm{PO}$ からの発表で光源の波長変動やフィルタの 製造誤差を考慮した時の多重可能な波長数を近 似的に求めたものである。また，回折格子や平 面導波路の応用として光分波器を設計すること も試みられており，計 4 件の発表があった。国 外から発表されたものとしては，図2に示すよ 


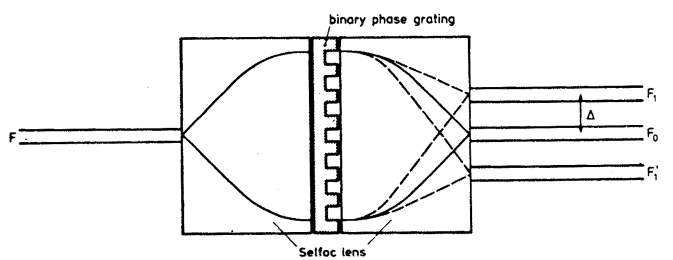

Fig. 2. Star coupler of binary-phase-grating type

うなbinary phase grating を用いたもの (Philips，独）や図３に示すような平面導波路 と回折格子を組み合わせたもの(Hughes，米) があるが, いずれもまだ提案段階であり, 今後 の研究が期待される。

Equipment and Techniquesというセッショ ンでは応用デバイスに関し 6 件の発表があり， そのうちの 3 件は日本からのものであった。 $\mathrm{BPO}$ からの発表はPIN ダイオードとSi-JFFT あるいはGaAs-MESFETを組み合せること により APDに近い高感度な受光器が実現でき

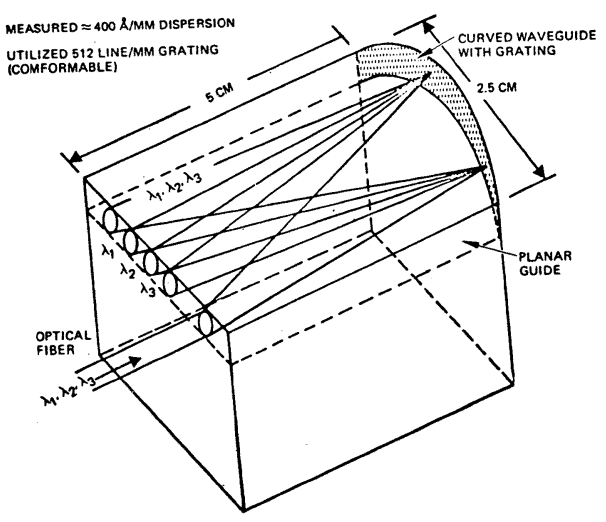

Fig. 3. Demutiplexer using a planar waveguide

ることを述べたもので， $2 \mathrm{Mb} / \mathrm{s}$ および 140 $\mathrm{Mb} / \mathrm{s}$ のディジタル伝送においてそれぞれー65 $d B m,-45 d B m$ の感度を実現している。日立 からのBHレーザーを用いて VHF 帯（70〜 $220 \mathrm{MHz})$ において 7 チャンネルのカラー $\mathrm{T}^{\prime}$ 伝送を行なったもので, intermodulation product <ー55dBを得ている。また光スイッチ について，図Aのような構造の $4 \times 4$ マトリッ クススイッチの発表が横須賀通研・日本電気か ら行なわれ，挿入損失 $0.3 \sim 1.3 \mathrm{~dB}$, クロスト 一ク 55dB以上が実現できることが述べられた。 光システムに関して2つのセション (System Studies，I，II）がもたれた。光ファイバの 最も大きな適用域は一般加入者であると予想さ れているが，七ションIの冒頭では独から

"Service integrated subscribcr lines in optical fiber technology” と題する招待論文 の発表があり，音声・デー夕・画像等のサービ スを光ファイバにより各加入者に提供するため の技術的課題等について講演した。HHI（独） からは70Mb/s でディジタル化した T V 信号を 16 チャンネル多重化して $1.12 \mathrm{~Gb} / \mathrm{s}$ とし, こ れをグレーディッドファイぐにより $3 \mathrm{~km}$ 伝送 したとの報告があった。また，松下電器および Naval Research (米) からは同一波長を使 った双方向伝送ならびにシングルモードファイ バを用いたデータバスの発表があつた。前者は 近端漏話量の低減化のため，コネクタ，カップ ラ等の話量を一 $56 \mathrm{~dB}$ 以下に抑えている。後者 は，単一モードファイバをより合せて $10 \times 10 の$ スターカプラーを実現したもので, 結合度のバ ラッキを小さくするため， 3 本のファイバをセ ット内，七ット間で交互によることによりバラ ッキを $2 \mathrm{~dB}$ 以下としている。 セッション II では34 Mb/s〜 560.Mb/sにわた る 5 件のディジタル光伝送実験の発表があった。 これらは光ファイバの公衆通信網（特に基幹回 線）への適用を狙いとしており，これまでにも 各国から数多くの発表が行なわれているもので ある。特に目新しい論文はないが独が $34 \mathrm{Mb} / \mathrm{s}$, $280 \mathrm{Mh} / \mathrm{s}, 560 \mathrm{Mh} / \mathrm{s}$ の各ビットレートで着寒 に実験を進めていると言える。全体的には 45 $\mathrm{Mb} / \mathrm{s}$ 以下のディジタル伝送については各国と も今会議で一通りの害験を終了したと言えよう。 2.4 光集積回路」関係

光通信システムが実用化段階に入りつつある 


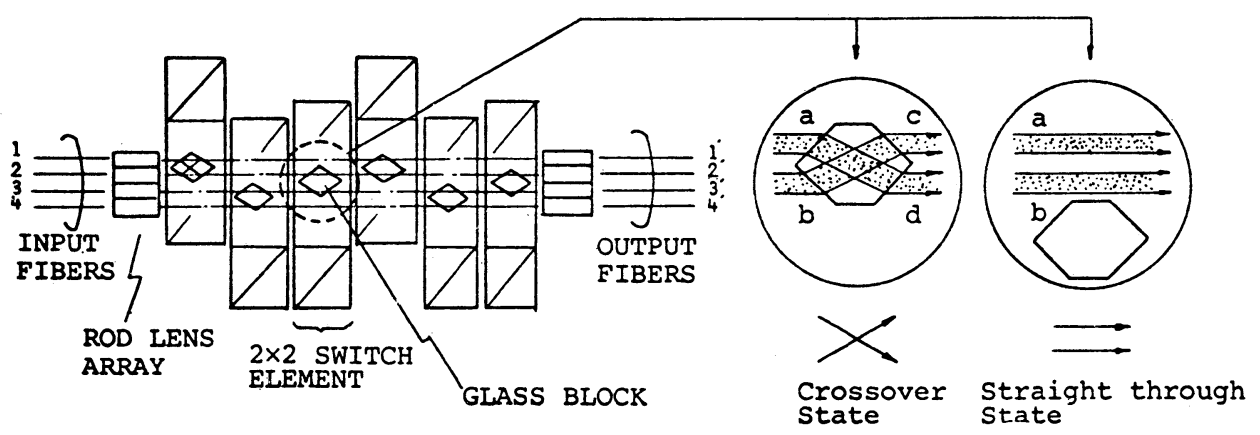

Fig. 4. Configuration of a $4 \times 4$ matrix switch

が，まだ各個部品は集積化の段階には到ってお らず，本会議でも光集積回路技術は将来技術で あるという印象をうけた。しかし，14件の発表 中には光集積回路に期待する機能について二三 の傾向がみられた。

第 1 は，単一モードファイバ・システムの開 発に対応するものである。単一モードファイバ 中では導波光の偏波面が一定していないため, これに接続する 3 次元導波路型のスイッチの特 性は偏波面に依存しないようにしておく必要が ある。B T LのAlfernessの発表はこの目的の デバイスの提案であった。

一方, 種々の素子を集積するのに必要な T E $\rightarrow \mathrm{T} \mathrm{M}$ モード変換器の研究が盛んであるが, 今 回阪大の井筒氏による高効率の変型周期構造形 の発表があった。電気制御機能を有する導波路 としては $\mathrm{LiNbO}_{3}$ をべースにした Ti 拡散線路 にほぼしぼらてきており，米国の Naval

Research Lab. からは製作法に関する詳しい 発表があった。

第 2 は波長多重機能を指向したもので, マイ クロ・グレイティングによる集積回路の試みが阪 大の西原氏，東大の榊氏から発表があった。前 者は微小なグレイティングを電子ビーム描画に よって作成するものであり，4 個の異なるグレ イティングの組み合せによる導波光分割用集積 回路の試作例を発表し，後者は 2 個のグレイテ イングによる波長分割回路例を発表した。

もうすこし複雑な信号処理機能をもつた光集 積回路の例は数少いが, その中でもよく知られ ているのが, NASA の要請で米国のいくつかの
企業の研究所で研究されている $\mathrm{RF}$ スペクトル アナライザである。この基板（約 $5 \mathrm{~cm}$ 角）とし て $\mathrm{LiNbO}_{3}$ と $\mathrm{Si}$ のどちらを選択すべきかについ て議論がつづき, 最近ようやく $\mathrm{RF}$ 特性の優位 さを重んじてLNに決定したという背景がある が, これに対して本会議では Rockwell

International の Anderson がSi を基板とし た RF スペクトルアナライザの現状とそのモノ リシック化の観点からみた将来性を力説してい た。

\section{もう一つの光集積回路の例にBattelle}

Columbus Research Lab. のVerber がこ 数年努力している高速マルチチャンネル・コン パレータがあり，今回はその後の進展状況を紹 介した。LN 基板上に16チャンネル（1チャン ネル幅 $4 \mu \mathrm{m}$ ）用の電極を作成しており，いか にも集積回路になりつ、あるという印象をうけ た。

\section{3. むすび}

今回の会議で, 現在の光通信技術における日 本の比重の大きさをあらためて認識させられた。 長波長の半導体レーザーの実現の見通しもつき， またファイバもいよいよ完成しつつある感じが する。したがって, 次は波長多重化などの光学 部品の関係の研究が一層盛んになると思われる。 研究者数が現在世界的にみて少し減少したよう にみえる光集積回路もこのときこそ出番であり， この方面での日本の活躍が期待される。2 年後 アメリカで開催予定の第 3 回 IOOC がたのしみ である。 


\title{
コンファレスレポート 2
}

\section{第11回原子衝突国際会議報告}

\author{
薮崎

\section{Report on XI International Conference on the Physics of Electronic and Atomic Collisions}

努*

\author{
Tsutomu YABUZAKI
}

第11回原子衝突国階会議は今年の 8 月29日か ら9月4日まで4日間（土，日曜日は休会）, 京 都の国階会議場で催された。会議のChairman はオランダのKristemakerで，過去20年間の 原子分子分光と題した Opening Iectureを皮切 りに始められた。一口に原子衝突と言ってもこ の会議で取り扱う粒子は原子のみでなく電子, イオン，簡単な分子，準分子及び光子にまで及 び, 従って極めて広い研究分野にまたがる大き な国際会議である。参加者の総数は 572 人（24 ケ国）で, 参加者の多い国から挙げると日本（ (277), 米国 (117), ドイツ (52), フランス (33), ソ連（16）, 英国（14）の順になる。こ の様な大きな会議にも拘らず, Iocal committee の chairmanである高柳教授を始めその member 達の御尽力により, 極めて効率良く話が聞ける 様構成されていた。本会議の大きな特徴は, 論 文の犬半を占めている contributed paperがポ スターセッションの形を取った点で, 大きな分 野にまたがる大会議には非常に良い方法である と思う。聞きたい論文があれば，ポスターの前 に行くだけで良いし，話す方も聞く方も緊張せ ずに 1 対 1 で会話ができるので, 講演の形で得 られない多くの情報が双方とも得られる。また 興味の無い話を強制的に聞かされないですむ点 も私にとってありがたかった。
本会議の構成は(1)Invited Lectures and Review Talks, (2) Progress Reports (3) 7 つの特定テーマに関する simposia (4) contributed papers（ポスターセッション） から成っ ていた。近年原子衝突の分野に於いても, 強力 かつ波長可変のレーザーの出現により, レーザ 一が非常に多く用いられている。本会議でも， 単に分光手段に用いるだけでなく，特定粒子の 特定準位に励起して衝突化学反応を研究するこ と,またlaser induced collisionの様に強い レーザー光の下でのみ生じる現象の様な active に利用したものも多く，ここで各論文（レーザ 一を用いた研究のみでも）を紹介するのは不可 能に近い。(1) (3)の講演の内容は近く本として 発刊される予定であり"(North-Holland)，ま た(4)の contributed paper のabstractは参加者 に配布されたので，詳細についてはこれらを読 んで戴きたい。

(1)の招待講演ではSchawlow が最近のレーザ 一分光の進歩と題して, 二光子共鳴や飽和分光 更にそれを改良したpolarization 分光について， 特にStanfordに於ける研究を中心に紹介した。 またLebedev 研究所の Sobel'manがUV及びX 線レーザーにおける衝突過程を議論し，100〜 $300 \AA$ の波長まで普通の共振器（normal indence）を用いて発振可能であることを示した。

* 京都大学工学部電離層研究施設

Ionospheve Research Laboratory, Kyoto University 
(3)のSimposiaではレーザーを用いた研究が多 く，下にプログラムを載げておく。特にレーザ 一と直接関連のある 3 つの Simpasiaが持たれ た。その1つ, stateresolved atom (ion)molecule ro-vibrationally inelastic and reactive scatteringでは，簡単な分子の回転 遷移に対する微分或いは全衝突断面積をレーザ 一蛍光法で測定するものが見られた。これは分 子の持定の初状態をレーザー励疑或いは四重極 レンズで与え，種々の終状態をレーザー蛍光法 を利用して観測するもので，DagdianがLiHに ついて ( $\mathrm{He}, \mathrm{HCl}, \mathrm{DCl}, \mathrm{HCN}$ の衝突), Bergmanが $\mathrm{Na}_{2}$ について $\left(\mathrm{H}_{2}\right.$ との衝突, fiber opticsを分光にうまく利用している）を報告し た。また近年盛んに研究が進められている Rydberg stateに関するSimposiumも持たれた。 Simposiumの題には分子の Rydberg state も 含む事になっていたが，実際には原子のみに限 られていた。Stebbingの総括的な話の後に， Delpech が電子との衝突（双極子相互作用がか なり主量子数の小さい状態 $(\mathrm{n} \geqq 10)$ まで重要 であると強調)，T.F.Gallagher が基底状態原 子や光子との衝突（黒体輻射との相互作用の重 要性を強調)，Rundelが分子との衝突，また Matsuzawa が中性粒子との衝突（電子衝突 モ デルを用いた理論）のreviewを行った。Simposiumの中で, 主量子数nの大きい方向への努 力はされているが，何故角運動量 Lの大きい状 態の研究がされていないかという質問も飛び出 していた。レーザー研究者にとって関心の深い と思われる強い輻射場中での衝突に関する Simposiumも持たれた。ここで取り扱われたのは， 列えば, $\mathrm{A}^{*}+\mathrm{B}+\mathrm{h} \nu \rightarrow \mathrm{A}+\mathrm{B}^{*}$ や $\mathrm{A}+\mathrm{B}+\mathrm{h} \nu \rightarrow$ $\mathrm{A}+\mathrm{B}^{*}$ の様な laser-induced energy transfer (absorption) や, $\mathrm{A}^{*}+\mathrm{B}+\mathrm{h} \nu \rightarrow(\mathrm{AB})^{*}+\mathrm{e}$ $\mathrm{A}^{*}+\mathrm{B}+\mathrm{h} \nu \rightarrow \mathrm{A}+\mathrm{B}^{*}+\mathrm{e}$ の様な ionizationや, $\mathrm{A}_{2}+\mathrm{B}_{2}+\mathrm{h} \nu \rightarrow 2 \mathrm{AB}$ の様な化学反応等で, Georgeが原子分子衝突，Andrickが電子一原 子衝突, Weinerがイオン一原子衝突に関する 最近のreviewを行った。(1)〜(3)の講演では既
に発表されている論文の

(1)〜3)の講演では既に発表されている論文の reviewがほとんどであったが，(4)の contributed paper（ポスターセッション）には全く 新しい結果の報告も多く大変興味深かった。し かし, contributed paperの総数は約560件もあ り，ここに個々の paperについて述べるのは不 可能である。先に述べた様に,このcontributed paperだけは，分厚なアブストラクト集が参加 者全員に配布されているので，興味をお持ちの 方は是非一覧される事をお勧めしたい。

この原子衝突国際会議は 2 年に一度催されて いるが，次回は1981年 7 月15〜21日に，米国の Gatlinbergで行なわれる。また1983年の次々会 にはBerlinが立候補しているということである。 参考の為に，以下に，Abstractが配布されな かったInvited Lecture and Review Talks とSimposiaのプログラムの内，レーザーに関 係の深いものを載げておく。

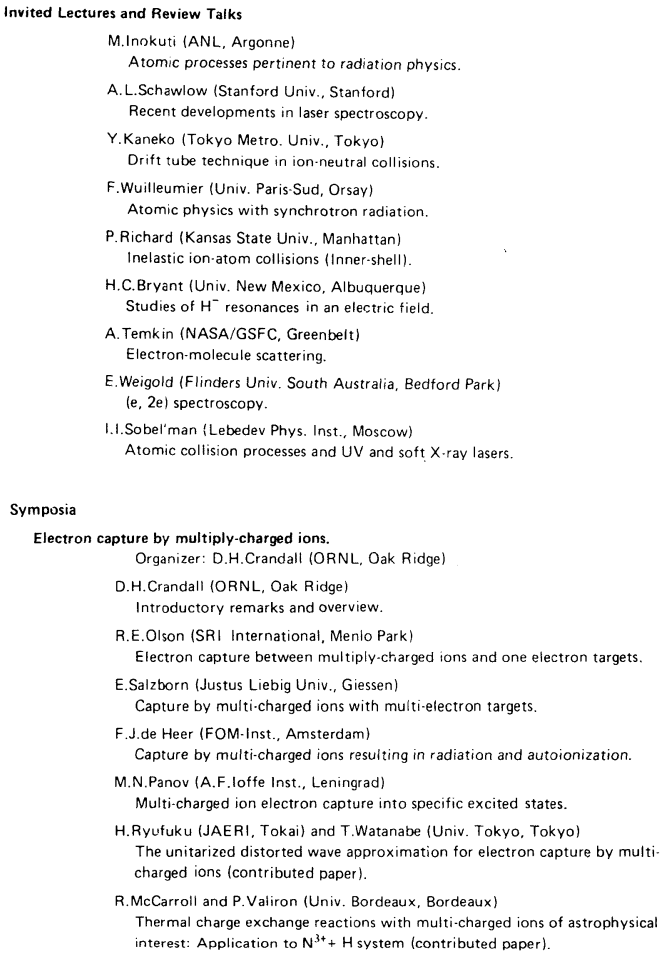


New experimental techniques.

Organizer: H.Suzuki (Sophia Univ., Tokyo)

S.R.Leone (JILA, Boulder)

New atomic and molecular lasers and their applications to the study of collision physics.

K.Jung (Univ. Kaiserslautern, Kaiserslautern)

Developments in techniques in high-resolution electron spectroscopy.

T.Arikawa (Tokyo Univ. Agric. Tech., Tokyo)

Applications of Hadamard transformation to beam spectroscopy.

W.R.Gentry (Univ. Minnesota, Minneapolis)

Pulsed molecular beam experiments.

B. Bederson (New York Univ., New York)

Developments in techniques for production of the quantum-state-selected atomic and molecular beams.

J.Los (FOM-Inst., Amsterdam

Application of channel-plate techniques in beam experiments.

New theoretical methods

Organizer: Yu.N.Demkov (Leningrad State Univ., Leningrad)

Macek (Univ. Nebraska, Lincoln)

Schwinger variational principle for Rydberg states.

W.P.Reinhardt (Univ. Colorado, Boulder) Atoms in fields.

R.Damburg (Inst. Physics, Riga)

Stark effect as a collisional problem.
Som

Vo Ky Lan (Obs. Paris, Meudon)

Recent theoretical development in electron-atom/molecule collisions.

Rydberg states of atoms and molecules.

Organizer: R.F.Stebbings (Rice Univ., Houston)

R.F.Stebbings (Rice Univ., Houston)

Introductory remarks.

J.F. Delpech (Univ. Paris XI, Orsay) Electron collisions with Rydberg atoms.

T.F.Gallagher (SRI International, Menlo Park

Collisions of Rydberg atoms with ground-state atoms and with photons.

R.D.Rundel (Rice Univ. and NASA, Houston)

Collisions of Rydberg atoms with molecules.

M.Matsuzawa (Univ. Electro-Commun., Tokyo)

Theory of thermal collisions between high-Rydberg atoms and neutra species.

State-resolved atom(ion)-molecule ro-vibrationally inelastic and reactive

State-resolved
scattering.

Organizer: J.P.Toennies (Max-Planck Inst., Göttingen)

J.P.Toennies (Max-Planck Inst., Göttingen)

Introductory remarks.

P.J.Dagdigian (Johns Hopkins Univ., Baltimore)

Laser fluorescence measurements of integrated cross sections for rotational transitions of state-selected lithium hydride.

K. Bergmann (Univ. Kaiserslautern, Kaiserslautern)

Laser fluorescence measurements of differential cross sections for rotational transitions of $\mathrm{Na}_{2}$.

F.Linder (Univ. Kaiserslautern, Kaiserslautern)

Energy loss studies of rotational and vibrational excitation in proton-

molecule scattering.

I. Koyano (Inst. Molecular Science, Okazaki)

State-selected reactive collisions of diatomic molecular ions by a coin. cidence technique.

J.Andres, U.Buck, F.Huisken, J.Schleusener and F. Torello (Max-Planck Inst.

Göttingen)

State-resolved $\mathrm{si}_{\mathrm{j}}=2$ rotational transitions in hydrogen molecule collisions (contributed paper).
Amplitudes and state parameters in atomic collisions.

Organizer: H. Kleinpoppen (Univ. Stirling, Stirling)

J.F. Williams (Queen's Univ., Belfast)

Angular correlations in atomic physics.

K. Blum (Univ. Münster, Münster)

Coherent and incoherent processes in atomic collisions.

R.Morgenstern (Univ. Utrecht, Utrecht)
Excitation of autoionizing states in heavy particle collisions studied by ionExcitation of autoionizing states in

N.Andersen, T.Andersen, J.Østgaard Olsen, E.Horsdal Pedersen, S.E.Nielsen and J.S.Dahler (Univ. Aarhus, Aarhus)

Coherence study of $\mathrm{Be}^{+} \cdot \mathrm{Ne}$ collisions: $180^{\circ}$ phase jumps for $\mathrm{Be}^{+}(2 \mathrm{~s}-2 \mathrm{p})$ excitation amplitudes (contributed paper).

B.Menner, J.Pfaff, B.Staudenmayer, L.Zehnle and V.Kempter (Univ. Freiburg Freiburg)

Alignment and orientation of $\mathrm{Li}(2 \mathrm{p})$ after collisional excitation by the molecules $\mathrm{H}_{2}$ and $\mathrm{N}_{2}$ (contributed paper).

R.Hippler, H.Kleinpoppen and H.O.Lutz (Univ. Bielefeld, Bielefeld) Determination of alignment tensor components for the charge exchange excitation of $\mathrm{H}(2 \mathrm{p})$ using a coincidence technique (contributed paper).

Electron detachment in negative ion collisions.

Organizer: J.S. Risley (North Carolina State Univ., Raleigh

J.S. Risley (North Carolina State Univ., Raleigh)

A review of negative ion detachment cross sections.

R.L. Champion (College William and Mary, Williamsburg) Experimental measurements of collisional detachment for energies near threshoild.

Yu.N. Demkov (Leningrad State Univ., Leningrad) Zero range Fermi approach in negative ion detachment.

J.P. Gauyaca (Univ. Paris-Sud, Orsay)

A theoretical study of the detachment process in $\mathrm{H}^{-}$plus $\mathrm{He}$ collisons.

A. Herzenberg (Yale Univ., New Haven)

The

Atomic and molecular collision processes under the influence of strong radiation fields.

Organizer: I.V. Hertel (Freie Univ., Beriin)

I.V.Hertel' (Freie Univ., Berlin)

Introductory survey.

T.F.George (Univ. Rochester, Rochester The theory of atomic and molecular collisions in the presence of strong radiation fields.

D.Andrick (Univ. Kaiserslautern, Kaiserslautern)

Free-free processes in electron-atom scattering: Experiments.

J.Weiner (Univ. Maryland, College Park)

Ion-atom collisions in the presence of a laser field: Experiment.

Ph.Cahuzac, C.Brechignac and P. Toschek (Univ. Heidelberg, Heidelberg) Light induced atomic collisions: Experimental verification of line shapes (contributed paper).

A.E.Orel and W.H.Miller (Univ. California, Berkeley) Enhancement of chemical reactions by collision induced absorption of in frared laser radiation: Theory (contributed paper). 


\title{
コンファレンスレポート 3
}

\section{第 9 回レーザーレーダー国際会議}

\author{
（昭和 54 年 10 月 22 日 受理）

\section{9 th International Laser Radar Conference \\ Nobuo TAKEUCHI*} \\ (Received October 22; 1979)
}

竹 内 延 夫*

第 9 回レーザーレーダー国際会議（9 ILRC） は1979年7月 2〜 5 日に, 西ドイツのミュンヘ ンの国際博覧会会場 (Fair Ground) で, 量子 エレクトロニクス国際会議 (IQEC) のヨーロ ッパ版ともいうべきLaser '79と同時に開催さ れた。9ILRCの主催者は米国気象学会である が, 米国光学会 (OSA) をはじめ 7 機関が共催 者として名を連ね, ドイツ航空宇宙局 (DFVL R) がホスト機関として会議の運営を行った。

ミュンヘンは1972年の夏季オリンピック開催 地として有名であるが, バイエルン州の中心と しての静かで古い文化都市で, 人口は130 万人 ほどである。ミュンヘンもドイッの他の都市と 同じく, 公共交通機関が発達していて, 同一ゾ ーン内を自由に高速鉄道 $(\mathrm{S}$ バーン, $\mathrm{U}$ バーン) や市電，市バスに乗りかえることができる。

9ILRC はパラレルセッションなし（1 会場 だけ）で朝 9 時（ 7 月 4 日だけ 8 時）から夜 6 時すぎまで，びっしりと詰まった日程で，9つ のセッションに分けて開かれた。参加者は全体 で206人で, 地元のドイッからは56人, アメリ カからは45人であった。過去 9 回のうちで, ア メリカ以外で開催されたのはジャマイカ, 日本
（仙台）に次いで 3 度目である。ヨーロッパで は初めてで, ヨーロッパ各国からは, フランス 22 人，英国 18 人，イタリア 12 人，スウェーデン 11 人と 2 桁の参加者があり, ソ連 $(4$ 人), オー ストリア ( 3 人 )，デンマーク (4人)，， ールゥェー ( 3 人) , オランダ ( 3 人), ベルギ - (1人), ポーランド ( 1 人), フィンラン ド（1人）東欧のチェコ（1人），ユーゴ（ 2 人)，ハンガリー（1人）とほとんどの国から 参加者があった。そのほかオーストラリアから 5 人の参加があったが，今回特筆すべきことは， 中国の大気物理研究所から4人が参加したこと であろう。日本からは稲場教授（東北大），五 十嵐氏(電波研) と私の 3 人が出席した。

講演発表の七ッション別, 国別の分類を Table 1 に示す。全体の講演申込数は 118 で, 何とい つてもアメリカの50件が最も多く, 次いで, 主 催国ドイツの16件, ソ連の13件と続き, 中国が 7 件提出しているのが注目された。さらに, 講 演内容を筆者の主観を混えて, ( I ) 計測手法を 主とするもの（装置・測定法, DIAL など）,

（II）測定およびその基礎としての色彩の強い もの（気象, エアロゾル, 多重散乱, 排煙）,

* 国立公害研究所 (

* National Institute for Environmental Studies, Yatabe, Tsukuba Ibaraki 305 Japan 
Table 19 th International Laser Radar Conference Munich July 2-5, 1979

\begin{tabular}{|c|c|c|c|c|c|c|c|c|c|c|c|c|c|c|c|c|c|}
\hline & Session & total & $\begin{array}{l}\text { カ } \\
\times \\
\text { J } \\
\text { カ }\end{array}$ & $\begin{array}{c}\text { 西 } \\
ト 5 \\
1 \\
ッ\end{array}$ & 連 & $\begin{array}{l}\text { 中 } \\
\text { 国 }\end{array}$ & 本 & $\begin{array}{l}7 \\
\text { ラ } \\
\text { ン } \\
\text { ス }\end{array}$ & $\begin{array}{l}\text { カ } \\
+ \\
\text { タ" }\end{array}$ & $\begin{array}{l}1 \\
\text { ギ } \\
\text { リ } \\
\text { ス }\end{array}$ & $\begin{array}{c}x \\
\text { I } \\
1 \\
\text { デ } \\
\text { ン }\end{array}$ & $\begin{array}{l}\text { 1 } \\
\text { 夕 } \\
\text { !) } \\
1\end{array}$ & 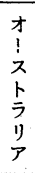 & $\begin{array}{l}\text { デ } \\
\text { ン } \\
\nabla \\
1 \\
\text { ク }\end{array}$ & $\begin{array}{l}\text { オ } \\
\text { ラ } \\
\text { ン } \\
\text { ダ }\end{array}$ & $\begin{array}{l}* \\
+ \\
\nabla \\
1 \\
\text { 力 }\end{array}$ & $\begin{array}{l}1 \\
\text { ン } \\
\text { ド }\end{array}$ \\
\hline 1. & $\begin{array}{l}\text { Wind, new instruments, and } \\
\text { analysis techniques }\end{array}$ & $19(1)$ & $6(1)$ & 3 & 3 & & 2 & 1 & 1 & 1 & & & & 1 & 1 & & \\
\hline 2. & $\begin{array}{l}\text { Tropospheric aerosols: } \\
\text { characteristies and } \\
\text { distributions }\end{array}$ & $19(3)$ & 7 & 2 & 4 (1) & $2(1)$ & $2(1)$ & & & & & & & & 1 & 1 & \\
\hline 3. & $\begin{array}{l}\text { Multiple scattering and } \\
\text { visibility }\end{array}$ & $16(1)$ & $5(1)$ & 4 & 0 & 2 & & & 2 & & & 2 & 1 & & & & \\
\hline 4. & Stratospheric aerosols & $13(1)$ & $\boldsymbol{9}^{*}(1)$ & 1 & 1 & & & 1 & & & & & & & & 1 & \\
\hline 5. & Spacelab lidar applications & 11 & 9 & 2 & 0 & & & & & & & & & & & & \\
\hline 6. & A tomic and molecular species & $18(1)$ & 6 & 2 & 1 & & 1 & 2 & & 2 & 3 & & & & & & 1 \\
\hline 7 . & Space lidar design & 4 & 3 & $1 * *$ & 0 & & & & & & & & & & & & \\
\hline 8. & Met eorological applications & 6 & 0 & 1 & 3 & 1 & & & & & & & & 1 & & & \\
\hline 9. & $\begin{array}{l}\text { Plumes and inhomogeneous } \\
\text { aerosol distributions }\end{array}$ & 12 & 5 & 0 & 1 & 2 & 1 & 1 & 1 & & & & 1 & & & & \\
\hline & Tot a 1 & 118 (7) & $50(4)$ & 16 & 13(1) 7 & $7(1)$ & $6(1)$ & 5 & 4 & 3 & 3 & 2 & 2 & 2 & 2 & 2 & 1 \\
\hline
\end{tabular}

* $(4-5)$ with Brazil \& Australia, $(4-11)$ with UK

** $(7-1)$ with France \& Netherland,

( $2-13)$ with FRG

\section{（）内は招待講演の数}

（III）応用（表示・解析, 環境・資源），（IV） 成層圏・宇宙に分けると, Fig. 1 のようになる。 9 ILRC 全体の印象をまとめると以下のように なる。

1. 成層圈・宇宙関係の研究が組織的に行われ るようになった。

2. エアロゾル関係では, $3 \sim 4$ 波長のレーザ 一光を同時に用いて粒径分布を推定する研 究が行われるようになった。また, 後方散 乱係数 $\beta(\pi)$ の鉛直分布が再び関心を持た れてきた。

3. 最も実用に近い研究として, 排煙の観測が 各国で行われている。

4. DIAL（差分吸収散乱ライダー）は次第に 実用に近づき, 水蒸気 $\left(\mathrm{H}_{2} \mathrm{O}\right)$ だけでなく, $\mathrm{NO}_{2}, \mathrm{SO}_{2}, \mathrm{O}_{3}$ の測定をフィールドで行え るシステムが現れてきた。
5 . 湿度（水蒸気圧）だけでなく，風（主とし てドップラーレーダー方式）や, 温度の測

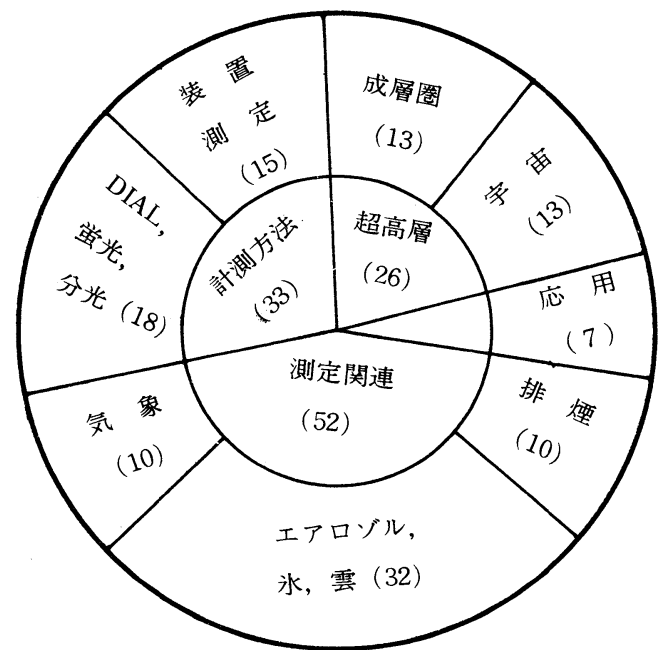

Fig. 1 Classification of talks at 9 ILRC 
定などの気象要素の測定が実用化に一歩近 づいた。

6. 赤外レーザー光源, 特に $\mathrm{CO}_{2}$ 赤外レーザ 一を光源とする赤外領域のレーザーレーダ 一の比率が増加している。

7. 測定データの表示・解析といったレーザー レーダーの応用・実用化に必要な手法の開 発に関する発表は少かった。

以下，講演の内容について筆者の注意をひい たものについて簡単に紹介する。

成層圏エアロゾルの観測は日本でも九州大学 名古屋大学で活発に行われているが（今回発表 なし）, NASA のLangley 研究所の McCormick らにより SAM II (Stratospheric Aerosol Measurements-II ) およびSAGE（Stratospheric Aerosol and Gas Experiment) の研 究の概要, 観測結果の解析, dustsonde や衛 星搭載フォトメータとの比較, 気球観測との比較 がなされた $(4-1 〜 6)$ 。また，レーザーレ 一ダー観測による成層圏エアロゾル濃度の短周 期の変化 $(4-7)$ や長期観測 $(4-9)$, フ ランスの CNRS のグループによる蛍光レーザ ーレーダーを用いた成層圏 $\mathrm{O}_{3}, \mathrm{Na}, \mathrm{Li}, \mathrm{K}$ の観 測やそれを用いた成層圏の温度プロファイルと 風速の測定など $(4-8,6-4,6-16)$ が 報告された。それに関連し, airborne レーザ ーレーダーの発表も行われた $(4-12) 。$

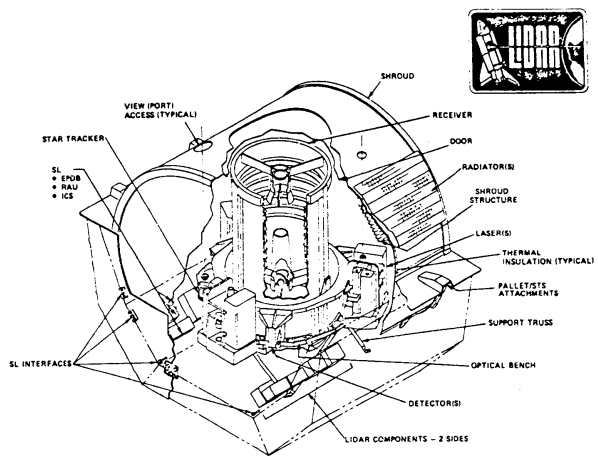

Fig. 1 Atmospheric lidar configurational arrangement of shuttle/spacelab.

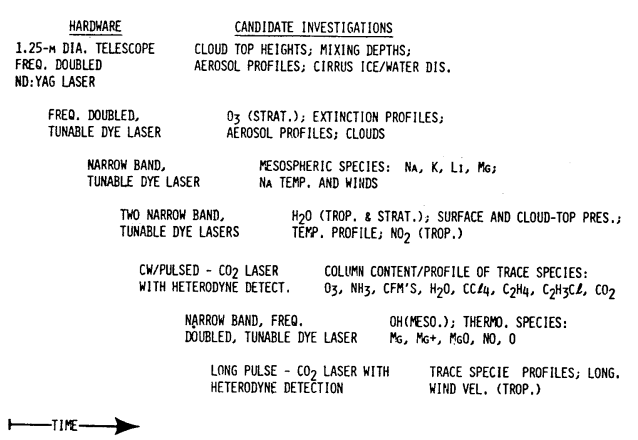

Fig. 3 Potential shuttle lidar evolutional growth

衛星搭載のレーザーレーダーについてもSpace lab/Shuttle 塔載の計画がNASA の Langley 研究所を中心として進められており，その内容 が紹介された（ $5-1 \sim 11,7-1 \sim 4)$ 。装 置はFig. 2 に示すようなデザインをしている。 望遠鏡は口径 1 〜 $1.25 \mathrm{~m}$ で, 図では開口部は 上方を向いている。レーザーはその周囲に配置 されている。Space Shuttle の計画は1980年か ら開始される。使用するレーザーは Fig. 3 の左 側のhard wareの闌に開発の時間の順に示さ れており, 右側にそれぞれのレーザー装置に対 応する測定項目が示されている。NASA では全 体を26の項目に整理している。雲高々度, 雲や エアロゾルのプロファイル, 地表面のアルビー ドー, 対流圏の圧力・温度分布などといった対 流圏の測定と, 成層圏 - 中間圏 - 熱圏などの超 高層のエアロゾル, オゾン, アルカリ原子, $\mathrm{O}$ $\mathrm{H}$ ラジカル, 微量成分気体などの密度; $\mathrm{Na}$ 濃 度から求められる温度や風の測定といった超高 層の科学の研究との 2 つのカゴリーから成っ ている。

次にエアロゾル関係について述べる。前回（ 8 ILRC ) の会議報告 1 で 2 波長 や偏光解消度 の測定によって，実在の粒子分布や成分の推定 を行う努力が為されていることを紹介したが， 今回は，2波長だけでなく，Nd：YAGレーザ 一とその第 2 高調波, ルビーレーザーとその第 2 高調波を組合わせて 3 波長， 4 波長を用いた 粒径分布の測定（2-9，11，14）が目をひい 
た。また, 光の減衰定数に対するミ一後方散乱 係数の比の高度変化や時間的変化の測定（2$1,8,14)$ や, 斜め視程 (slant visibility) の測定の検討 $(3-1,2,4)$ が報告された。 多重散乱についても, 水や雲を対象に研究が続 けられている。

Shipley (Wisconsin 大学) は, 中性鉄原 子のFraunhofer 線 $(467.8 \mathrm{~nm})$ で, $0.13 \AA$ に わたって太陽光が吸収されている現象を利用し て, スペクトル幅の狭い色素レーザー光を光源 とし, 多重エタロンによってミ一散乱・レーリ 一散乱の高分解能散乱スペクトル (Fig. 4) を 測定し, 中央の鋭いピークのスペクトルと裾と の比から, 大気の分子密度とエアロゾル密度を 精度よく求めることに成功した。これはFiocco が行った実験を $467.8 \mathrm{~nm}$ で行うことによって 背景太陽光光度を 1 桁下げたことによる。（2 -10)。

排煙の拡散・移流はレーザーレーダーが実地 に応用されている最も良い例である。ロビーで 耳にした話であるが，米国ではレーザーレーダ 一が排煙の透明度を測定する装置として79年 12 月から法律で認められる由であった。その根拠

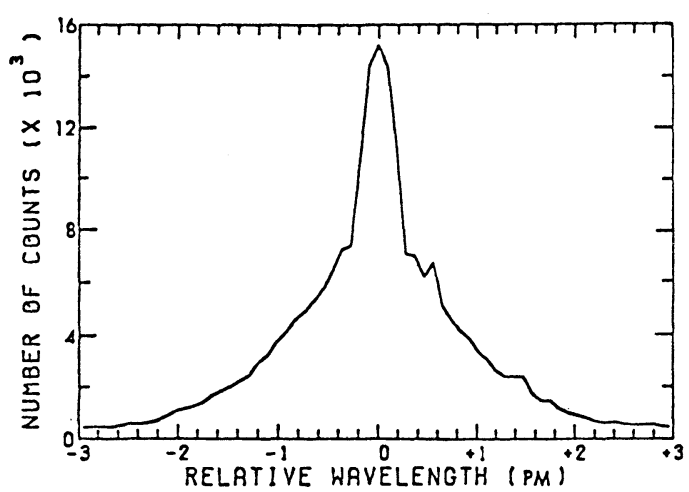

Fig. 4 Spectrum of the light which is backscattered by the atmosphere as a function of dye laser output wavelength near $467.8 \mathrm{~nm}$. In this test, the signal was integrated over the first 20 range bins, which corresponds to a vertical slab length of $600 \mathrm{~m}$ at a height $\sim 1 \mathrm{~km}$. The abscissa is given in units of $1 \mathrm{pm}$ $=10 \mathrm{~mA}$.

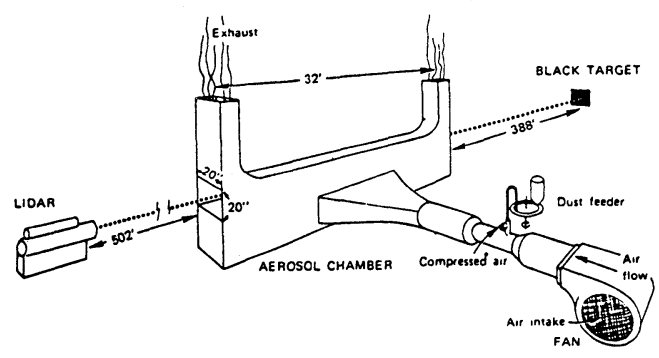

Fig. 5 Diagram of experimental system for lidar oracity measurement.

となった排煙の透明度のレーザーレーダーと透 過率測定器 (transmissiometer) との比較を, 工 アロゾルチャンバーを用いて行った実験がス夕 ンフォード研究所（SRI） から報告された（9 -1, Fig. 5)。現在, 石油価格の高騰から石炭 エネルギーへの転換が問題となっているが, 米 国中東部では豊富な石炭を利用して石炭による 火力発電が継続して行われてきた。これらの排 煙は $1,000 \mathrm{~km}$ の遠方にも達し, 米国東海岸の大 都市や，越境してカナダの森林に影響を及ぼし ている。SRI では車載型のミ一散乱レーザーレ 一ダー (Mark IX)を用いてハイウェイを走行し ながら排煙の流れを観測している（9-2）。 また，カナダの環境省ではエリー湖畔のコンビ ナートの工場からの排煙が湖陸風や湖風前線に よって“いぶし現象”を起こす状態をレーザー レーダー, 飛行機, ヘリコプター, 車載の相関 分光計 (COSPEC), 係留気球，低層ゾンデを 用いて総合的に観測している $(9-3)$ 。国立 公害研究所の計測車レーザーレーダーシステム も排煙観測実験に関連して同じセッションで発 表された $(9-8)$ 。他所ではレーザーの繰返 しは20〜40pps ほど高速ではなく，排煙のよう うに早く変化する現象も長時間を要して測定し ている。その点で国立公害研のシステムは 2 5 秒で一断畺が得られ, 必要に応じてパターン データの積算も可能であり, ユニークな存在で あろう。

前回, DIAL についてはシステムの試作の発 表が多かったが, 今回は測定システムとし.て完 
成され，実際にフィールドでの観測が報告され た。車載型については英国 $(6-7)$ とスウェ ーデン（6-18）念ら報告された。前者は現在， 色素レーザー（CM X 4) を装備して排煙中の $\mathrm{SO}_{2}$ を測定しているが, 将来は色素レーザーに

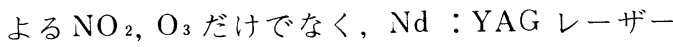
励起のパラメトリック発振器 ( $1.4 \sim 4.0 \mu \mathrm{m})$ を整備し，他の微量污染気体の測定も計画して いる。後者はNd：YAGレーザーの第 2 高調 波で色素レーザーを励起し, さらにその第 2 高 調波を利用して $\mathrm{SO}_{2}, \mathrm{NO}_{2}$ を測定している。 $\mathrm{CO}_{2}$ レーザーを用いた研究は, ドップラー型のレー ザーレーダーによる風の計測 $(1-2 \sim 4)$, 大気伝幡 $(1-16)$ や測距 $(1-17)$ に用いる 研究報告もなされているが，DIALでも，浅井 (電波研) らは，5.5.Jの $\mathrm{CO}_{2} レ$ レ゙ーを用い て20〜40ppb の $\mathrm{O}_{3}$ 濃度を測定している（65 ) 。Baumer ら(ミュンヘン大学)は $\mathrm{CO}_{2} レ$ ザーDIAL システムを車載して，化学工場上空 のエチレンを10〜20ppbの濃度まで測定してい る $(6-2)$ 。

気象要素に関する溝演は視程以外にも，風， 湿度，温度を合わせて13件を数えた。報告され た風の尌測に関する報告（ $1-1 \sim 5,5-5)$ はドップラーシフトを利用古るものが主であっ た。湿度の鉛直プロファイルの測定については, Schotland 2 が最初に報告したのと同じくルビ ーレーザーを用いた方法が，ソ連（８-1）， ドイツ $(8-2)$ と中国 $(8-3)$ から報告さ 机た。NASAではNd:YAGレーザー励起の 色素レーザーで 690 〜 760 nm を用いて温度と 湿度を回昍持に測定するシステムを胡画している $(5-9)$ 。

この会議の性格でもあるが，講演はレーザー レーダーに関古る基礎的・理論的研究, 新しい 提案, 大気現象の観測や験証実験が主であって, レーザーレーダーを㖕測手段として用いる場合 にその周辺技術の開抔を行っていく研究は極め て少い。そのような点から村上ら（阪大）のレ ーザーレーダーのデータのパターン認識手法に
よる研究（2-16）や清水ら（国立公害研）の 表示法の検討（1-11）は希少価値があろう。 環境計測への応用としては，稲場（東北大）に よって, 日本のレーザーレーダー研究の現状や火 山噴煙観測計画の紹介とともに，オプティカル ファイバーを利用して多地点の污染気体濃度を 同時にレーザー光吸収計測で測定する方法の提 案があった $(2-2)$ 。

中国の 7 件の講演は全て中国科学院大気物理 研究所からのもので, そこでは大気減衰状態の 鉛直分布を始めとして, 排煙の観測, ルビーレ ・ーザーDIALによる温度の観測や斜め視程など が行われており, 非常に基礎的研究を地道に行 っているという印象を受けた。

涅後に公議の終了後に催されたミュンヘン大 学, DFVLR およびInstitute of Atmospheric Environmental Research (IAER) ヘ૦ッアー について触れてこの稿を終えたい。

ミュンヘン大学はマックスプランク研究所の レーザー研究部門と同一構内にあり,ミュ ンヘンの中心部から北北東 $10 \mathrm{~km} の$ Garching に 位置する。周囲は緑に囲まれ，落ちついた研究 環境にある。ツアーは7月 5 日 W alther 教授が 主催して行われた。参加者はZuev (ソ連) や Kelley (MIT), Byer (Stanford 大) の約20 人であった。マックスプランク研究所は大出力

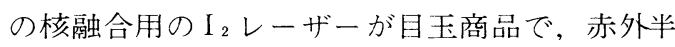
導体レーザーを用いた分光実験もここで行われ ていた。レーザーレーダーの実験はミュンヘン 大学の方で行われており, $(6-2)$ の講演に あった装置（Fig. 9）を見ることができた。こ のIR-DIAL システムの仕様をTable 2 に示 す。性能としては, $\mathrm{H}_{2} \mathrm{O}, \mathrm{C}_{2} \mathrm{H}_{4}$ に対し, 長光路 計測では 1 ショツトで20ppb (光路〜 $700 \mathrm{~m}$ ) を得ており, DIAL 法では $20 \mathrm{~m}$ 程度の空間分解 能で10〜20ppb の検出感度を得るのに1000ショ ット以上の積算を必要としている。平面パター ンを得るには，一方向50ショツト（2.5秒）ず つ積算しながら一平面のデー夕を得るのに 1 時 間を要している。このシステムで化学工場附近 
の $\mathrm{C}_{2} \mathrm{H}_{4}$ を測定したことは前に述べた。

翌日, DFVLR によってチャーターされた観 光バスで DFVLR およびIAER へのツアーが あった。DFVLR はミュンヘン大学と正反対の 方角のOberpfaffenhofen にあり，ここでは航 空および宇宙, 大気, 光通信, 電気通信の研究 を分担している。レーザーレーダーはそのうち 大気の研究および測距の研究に用いられている。 ミュンヘン郊外にある研究所はDFVLR の中で は 2 番目に大きく, 職員数は研究者 1,008 人, 技術員 1,283 人，事務およびパート 912 人，計 3,153 人である。レーザーレーダーは大気境界層, 成層圈および大気污染の研究用として各種製作 されており，特にフィールド観測用として三脚 にのせて使用する可搬型のもの, コンテナに収 納された移動型, および航空機搭載型を所有し, フィールド観測を行っている。可搬型のレーザ 一の仕様をTable 3 に示した。

Table 2 Specification of the IR-DIAL at the University of München.

\begin{tabular}{l|l}
\hline Laser & $\mathrm{CO}_{2}$ TEA Laser(Lumonix) \\
\hline Energy/pulse & $1 \mathrm{~J}, \quad$ Pulse width $100 \sim 200 \mathrm{~ns}$ \\
\hline Repetition rate & typ. 20pps, max. 70pps \\
\hline Telescope & $60 \mathrm{~cm} \phi$ \\
\hline Detecting gases & $\mathrm{H}_{2} \mathrm{O}, \mathrm{C}_{2} \mathrm{H}_{4}$ \\
\hline Detectivity & $10 \sim 20 \mathrm{ppb}$ for $\triangle \mathrm{R} \approx 20 \mathrm{~m}$ and \\
& 1000 shots average \\
\hline
\end{tabular}

Table 3 Specification of the portable lidar at DFVLR.

\begin{tabular}{l|l}
\hline Laser & Nd:Glass laser (Zeiss) \\
\hline Wavelength & $1.064 \mathrm{pm}$ \\
\hline Output power & $3 \mathrm{MW}$ \\
\hline $\begin{array}{l}\text { Outpnt energy } \\
\text { Pulse duration }\end{array}$ & $0.15 \mathrm{~J}$ \\
\hline $\begin{array}{l}\text { Max. repetition } \\
\text { rate }\end{array}$ & $1 \mathrm{~Hz}$ \\
\hline $\begin{array}{l}\text { Detector } \\
\begin{array}{l}\text { Telescspe } \\
\text { diameter }\end{array}\end{array}$ & $13.4 \mathrm{~cm}$ \\
\hline
\end{tabular}

IAER はオーストリア国鏡に近いチロル地方の 山麓にあり, 総勢20人程度の小じんまりした研 究所である。Nd：YAGレーザーのSHG とル ビーレーザーおよびその SHG の 3 波長で成層 圏エアロゾルの常時観測（晴天の夜間のみ）を行 っているほか, 附近の山頂やケーブルカー駅に 観測器を置いて, エアロゾル, 気温, 気圧, 湿 度, 大気電気, $\mathrm{O}_{3}, \mathrm{CO}_{2}, \mathrm{NO}, \mathrm{NO}_{2}, \mathrm{SO}_{2}, \mathrm{Rn}$, 炭化水素や視程の観測を行っている。観測の模 式図をFig. 6 に示した。見学時に, 最近完成さ れたばかりという車載型の Nd : YAG, ルビー 両レーザーを搭載したレーザーレーダー車が公 開された。本体はトレーラーに引かれ，電源と 操作・デー夕収録用マイコン部分がバン部分に 収納されている

INSTITUTE FOR ATMOSPHERIC ENVIRONMENTAL RESEARCH

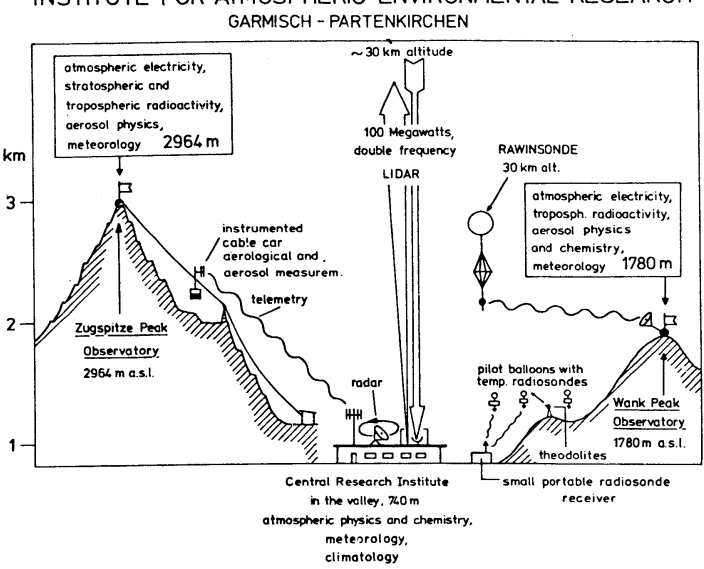

Fig. 6 Schematic explanation of IAER activity.

以上, 9 ILRC の印象を述べた。会議自体は 主催国のドイシ人の性格を反映してぎっしりつ まったスケジュールを非常に凡張面にこなして 運営された。また, 会議 1 日目の夜開かれたバ 一バリアン・ディナーは非常に楽しいものであ つた。運営委員長のDr.Ch.Werner に心から 感謝の意を表する。

\section{引用 文 献}

1) 竹内延夫：電通学会誌, 60 (1977) 1435 .

2) R. M. Schotland: Proc. 3 rd Symp. on Remote Sensing of the Environment (Ann Arbor, 1964) 215 . 


\section{コンファレンスレポート 4}

\section{エキシマーレーザーに関するトピカル \\ ミーティングの報告}

豊田浩 一*

\section{Report of Topical Meeting on Excimer Lasers}

(Sep. 11-13，1979)

$\mathrm{OSA}$ 主催のエキシマーレーザーに関するト ピカルミーティングが1979年 9 月11日から13日 に米国サウスカロライナ州，チャールストン市 において開催された。その会議に出席する機会 を得たので概略の様子を報告したい。

この会議に提出された論文は56件，ポストデ ッドラインペーパーは10件であった。会議は理 論関係の 5 件の講演を除いて, すべて単一のセ ッションで催された。提出された論文の研究機 関別の内訳は表 1 に示す。また米国以外より提

\section{表 1 研究機関別論文数}

$\begin{array}{lrr}\text { LLL } & 11 \\ \text { NBS } & & 5 \\ \text { LASL } & & 4 \\ \text { NRL } & & 2 \\ \text { その他大学関係 } & & 11 \\ \text { 会社関係 } & & 16 \\ \quad \text { 米国合計 } & 48 & \\ \quad \text { ドイッ } & 3 & \\ \quad \text { イギリス } & 3 & \\ \quad \text { イスラエル } & 1 & \\ \quad \text { 日本 } & 1 & \\ \quad \text { 計 } & 56 & \end{array}$

出されたものは国別の数を示す。なお，参加者 数は約 140 名であった。各セッションに付され たテーマと論文数は表 2 のようになっている。

表 2 セッションのテーマと論文数

第1日 Rare Gas Halides I

Rave Gas Halides and Rare Gas Excimers

2日 Rare Gas Halides II 9

Technology 6

Theory 5

第3日 Rare Gas Halide Applications 8 Mercury Halides and Metal Excimers 9

会議の第 1 日はプログラム委員会のチェアパ ーソンである Rhodes の Opening Remarks から始められた。彼は1972年より79年までにな されたエキシマーレーザーに関するいろいろな 研究成果を紹介したあとレーザーパワーの向上

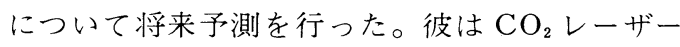
を例にあげ1965年頃平均出力が $\mathrm{mW}$ 程度であっ たパワーは1979年には $10^{5} \mathrm{~W} に も$ 達していること を指摘し，一方エキシマレーザーの年年のパワ 一増大の傾向が $\mathrm{CO}_{2} レ$ レ゙ーの初期の頃とよ く似ていることから将来は $\mathrm{CO}_{2} レ$ レ゙ーに匹敵

* 理化学研究所レーザー科学研究グループ（テ351 和光市広沢 2-1）

* Laser Science Research Group. The Institute of Physical and Chemical Research (2-1, Hirosawa, Wako, Saitama 351) 
する高出カレーザーに生長すると予想していた のが印象に残った。Rhodes の話だけではこの 予想が必ずしも根拠のあるものと思われなかっ たが，会議全体を省みると彼は分光学的デー夕 が精密に得られつつある現状や技術的進歩を十 分理解した上でこのような予想を行ったと理解 された。

さて, 表 2 から判るように希ガス八ライド系 エキシマーレーザーの発表が全体の $60 \%$ にもな っているので, これらを中心に述べてみたい。 今回のトピカルミーティングの発表論文の内容 は，大別してみると一つはレーザー準位の kinetics に関するもの，他は高出カレーザー を実現するための technology に関するもので ある。

まずkinetics に関してはエキシマーのB準 位と $\mathrm{C}$ 準位のミキシングがどの位の速さで起っ ているかについて多くの発表があった。通常工 キシマーには $\mathrm{B} \rightarrow \mathrm{X}$ 遷移と $\mathrm{C} \rightarrow \mathrm{A}$ 遷とがあり, ミキシングの程度がレーザー特性に影響を与え るからである。そのレート定数や, 圧力, 温度 電流密度等の影響につき発表された。以下お よそ発表の順序にしたがって記す。

ウエスチンングハウスのKline らは selfsustained dischargeによってパルス幅 300 ns という長時間の放電を行い, $\mathrm{XeF}$ の $\mathrm{B} \rightarrow \mathrm{X}$ および $\mathrm{C} \rightarrow \mathrm{A}$ 遷移の螢光強度を観測している。 この実験において C 準位と B 準位の分布密度の 比 $\mathrm{n}_{\mathrm{c}} / \mathrm{n}_{\mathrm{B}}$ を Xe の圧力および放電電流の関数と して求めているが Xe 圧力が 1 Torr を越える とC準位がquenching を受けること，電流值 の増大につれて B 準位, C 準位の mixing が起 ることなどを示している。

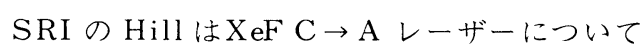
招待講演を行った。 5 気圧の Xe ガスを電子ビ ームでポンピングし， Xeエキシマーの発光で $\mathrm{Ar} / \mathrm{XeF}_{2} / \mathrm{SF}_{6}$ 混合ガスを光解離させ螢光収量 のガス圧力依存性, C準位の quenching レー 卜等について述べた。光解離ポンピングの場合, 電子ビーム, 放電などの場合とくらべて発振入 ペクトルの構造が簡単であることから, 特定の
振動準位しか励起されていないのではないかと いう推測がなされた。また C 準位の quen ching に関しては $\mathrm{Xe}, \mathrm{NF}_{3}$ 等はその断面積が小さい が, $\mathrm{XeF}_{2}$ はそれらより1桁断面積が大きいの で quenchingの効果が無視されない。

同じくSRIのBlack らはSSRLのシンクロ トロンより放射される $\mathrm{SOR}$ 光を用いて $\mathrm{XeF}_{2}$ の光解離による $\mathrm{XeF}(\mathrm{B}, \mathrm{C})$ の計測を行ってい

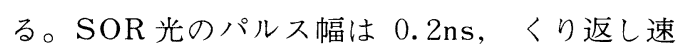
度 $1.28 \times 10^{6} / \mathrm{s}$ で励起光のスペクトル幅は 0.1 $\mathrm{nm}$ である。この結果では $160 \mathrm{~nm}$ 吸収帯での $\mathrm{XeF}_{2}$ の吸収断面積, $6.4 \pm 0.6 \times 10^{-17} \mathrm{~cm}^{2}$ を 得ており,また B, C, D 準位を加えるとほぼ100 $\% \mathrm{XeF}$ エキシマーが出来ているとされた。バッ ファーガスの効果として Ar, $\mathrm{Ne}, \mathrm{N}_{2}$ などの反 応プロセスとそれぞれのレート定数が求められ ている。

Max-Planck のPummer らは放電励起の $\mathrm{KrF} レ$ レー゙ーの側光の測定から B, C, D 準位 の結合の強さを求めている。彼らは放電の側光 をレーザー光に含まれる部分と含まれない部分 の 2 個所で測定し，それぞれの時間変化よりレ ーザー引出しエネルギーへの寄与を討論した。

B 準位は $248.5 \mathrm{~nm}$ のレーザー発振開始と同時 に急激に減少し，また $\mathrm{C}$ 準位もそれにつれて減 少する。この時定数は $1 \mathrm{~ns}$ 以下と見積られる。 それに対しD準位の時定数は $20 \mathrm{~ns}$ 以下であって ほとんど奇与していないことを示した。

LASLのSzeも XeClについて同様な側光 の時間分解測定を行っている。またレート方程 式より各準位の寿命, quenching のレート定数 などを見積っている。

LLLの Powell らは電子ビーム励起によっ て生成した $\mathrm{Xe}_{2}$ エキシマーからの発光により 172 $\mathrm{nm}$ のVUVを $0.8 \times 8.5 \mathrm{~cm}$ の $\mathrm{MgF}_{2}$ 空を通して $\mathrm{XeF}_{2}$ に照射した時の $\mathrm{XeF}$ のレーザーの発振お よびkineticsについて発表した。このポンプ 光の強度は $5 \mathrm{MW} / \mathrm{cm}^{2}$ である。

Rice Uhiv. のPollock らはPhysics International 社のモデル110 A電子ビーム装 置を肌て，XeFレーザーの研究を行っている。 
この電子ビーム装置は $1 \mathrm{MeV}, 20 \mathrm{KA}, 8 \mathrm{~ns}$ の 電子ビームを放出し $6 \times 1 \mathrm{~cm}$ のガスを横方向よ りポンピングする。彼らは $600 \mathrm{KPa}$ の $\mathrm{N}$ e と $\mathrm{Ar}$ とをバッファーガスとして用いて, ガス温 度を $300 \mathrm{~K} よ り 600 \mathrm{~K}$ まで変えてレーザー出力, 螢光強度の変化を求め討論している。一例とし て $300^{\circ} \mathrm{K}$ においては353nm の強度が $351 \mathrm{~nm}$ り大であるが， $580{ }^{\circ} \mathrm{K}$ においてはそれが逆 転 すること，バッファーガスが $\mathrm{Ar}$ と $\mathrm{Ne}$ 場合で 温度特性が異なること等に関し討論した。

RSI のHuestisは $\mathrm{Ar}_{2} \mathrm{~F}, \mathrm{Xe}_{2} \mathrm{~F}, \mathrm{Kr}_{2} \mathrm{~F}, \mathrm{Xe}_{2} \mathrm{Cl}$ $\mathrm{Xe}_{2} \mathrm{I}$ など希ガスハライド 3 原子エキシマーに 関して招待講演を行った。 $\mathrm{Ar} / \mathrm{Kr} / \mathrm{F}_{2}$ 系では Kr の圧力を10Torr 近辺より200Torr 位まで 増すと $\mathrm{KrF}$ の $248 \mathrm{~nm}$ の螢光強度が次第に低下 するのに対し， $\mathrm{Kr}_{2} \mathrm{~F}$ の $400 \mathrm{~nm}$ の強度が強め られて行くことを示した。3原子エキシマーは bottle-necking がないので効率が高いと予想 されている。しかしながら自己吸収やバックグ ラウンドの吸収が問題であることを指摘してい る。

Hebrew Univ のRokni らは Xe/ $\mathrm{NF}_{3}$ 系を 用い, $\mathrm{B} \rightarrow \mathrm{X}$ 遷移強度の圧力依存性を調べ $1 / 2$ atm 度でも B， C のミキシングが起っている

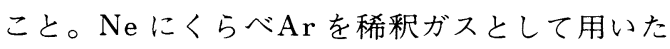
とき $\mathrm{C} \rightarrow \mathrm{A}$ 遷移にレッドシフトが起ることなど を報告した。また自然放出寿命として $\tau_{\mathrm{C}} / \tau_{\mathrm{B}}=$ 9.3， Bと Cのエネルギー差が $0.01 \mathrm{eV}$ 程度で あること等に関し討論を行った。

次にAVCOの Jacobらによって電子衝室に よるエキシマーの quenching に関する招待講 演があった。彼らは電子ビーム励起のエキシマ ーレーザー中の $\mathrm{F}_{2}$ 濃度を $0.5 \sim 4$ Torr まで変 えたとき, 電子密度が $2.2 \times 10^{14}$ から $0.2 \times 10^{14}$ と約 1 桁小さくなることを利用してこのレート 定数を求めた。用いられた電子ビームは加速電 圧 $150 \mathrm{KV}$, 電流密度は $1 \sim 15 \mathrm{~A} / \mathrm{cm}^{2}$ で 0.001 mm厚のKapton foilを通して $1.5 \mathrm{~cm}$ 厚のガス媒 質中に導入している。

knetics やそれに関係した測定技術は実にい ろいろあって参考になることも多かったがこれ
以上書いてもあまり意味があると思われないの で次に高出カレーザーに関する発表について記 す。

まずSandia Labo, のTisone らの発表では $1.5 \mathrm{MeV} 85 \mathrm{KA}$ の電子ビームを $7.5 \mathrm{~cm}$ 径, $90 \mathrm{~cm}$ 長のセル中に打込み, 圧力2500Torr において $\mathrm{KrF}$ レーザー出力 $80 \mathrm{~J}$ を得ている。単位出力エ ネルギーでは圧力1000Torr において12J/1 あ るいは 9.2J/1 - atm 圧力2500Torr において $40 \mathrm{~J} / \mathrm{l}, 12 \mathrm{~J} / \mathbf{l} \cdot \mathrm{atm}$ になる。レーザーの活性長 は $40 \mathrm{~cm}$ であり $\mathrm{goL}=7 ， \alpha \mathrm{L}=0.45$ とおいたシ ミュレーションの結果とよい一致を示した。ま た最大の効率は〜 $13 \%$, 電子ビームの energy deposition rate は1000Torr において $2 \mathrm{MW}$ $/ \mathrm{cm}^{3}$, 2500Torr において $7 \mathrm{MW} / \mathrm{cm}^{3}$ であった とされている。

LLLでは将来 $10 \mathrm{KHz}$ のくり返し速度で $10 \mathrm{~J}$ /パルス, 平均パワー100 kWのものを目ざして 研究を通めている。そのための電子ビームの開 発, foil の加熱の問題, ビーム伝搬の研究を継 続している。この電子ビーム装置は大型のクラ イストロンかあるいは小型の電子線ライナック といった感じのものである。ちなみに彼らの試 算では $100 \mathrm{~kW}$ 級のもので建設費は 50 ドル $/ \mathrm{W}$, $10 \mathrm{~kW}$ 級のもので 220 ドル/Wということである。

同じく LLLの Rapoport らの報告では, 電 子ビーム励起の $\mathrm{KrF}$ レーザーで14J の出力を 得ているが,これに $1.87 \mathrm{~mJ} の$ injection locking を行ったとき出力エネルギーは20.3に 増大したということである。またスペクトル幅

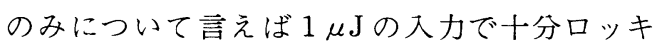
ングがかけられると述べている。

Westinghouse の Kline はいろいろなkinetics のデータに基ずいて XeFレーザーの効率につ いて招待講演を行った。彼によれば, 放電を安 定させるには $\mathrm{E} / \mathrm{N}=2 \sim 5 \mathrm{KV} / \mathrm{cm} \cdot \mathrm{atm}$ にする のがよいが, 効率は $\mathrm{E} / \mathrm{N}, \mathrm{Xe}$ 圧力を大きくし, 電流密度は小にした方がよくなる。結論として 短パルスでは $13 \sim 17 \%$, 長パルスでは $3 \sim 6 \%$ である。効率を制限している要因は onset delay, bottle-necking および, transient 
absorptionである。

AVCOのPike はくり返し速度 $10 \mathrm{kHz}$ の $\mathrm{XeF}$ レーザーの特性について発表した。これは UV 予備電離方式である。ガスの流速を $100 \mathrm{~m} /$ $\mathrm{s}$ とし干渉計で放電後の衝撃波の伝播のようす を解析し $10 \mathrm{kHz}$ のくり返し時間ではレーザー媒 質の均一性が回復していることを確かめている。 彼らの最初の装置ではは $2 \mathrm{kHz}$ までは安定であ ったが $7 \mathrm{kHz}$ では発振が不安定となった。そこ で放電管壁に音響的ダンパーを設けることによ り $10 \mathrm{k} \mathrm{Hz}$ の発振に成功している。効率は $0.3 \%$, 出力 $50 \mathrm{~mJ} /$ パルスを目標としているが, エネル ギーはまだ $60 \%$ 程度のようである。

LLLの Miller らは循環型のレーザーの発振 特性につき発表した。結果のみ示すと $\mathrm{XeF}$ で $50 \mathrm{~mJ} /$ パルス, 平均パワー16W, くり返し速度 $500 \mathrm{~Hz}$ でガス寿命は30分である。以下この順 序で XeCl, $100 \mathrm{~mJ}, 45 \mathrm{~W}, 600 \mathrm{~Hz}, 2.5$ 時間, $\mathrm{KrF}, 145 \mathrm{~mJ}, 26 \mathrm{~W}, 300 \mathrm{~Hz}, 2$ 時間ArF, 47 $\mathrm{mJ}, 7 \mathrm{~W}, 400 \mathrm{~Hz}, 15$ 分である。入力エネルギー は38kV，15Jである。

LASLの Tallman は予備電離方式のいろい ろの形式について系統的に実験を行った結果を 報告した。その結果コロナスパークを使ったも のが一番よいと結論している。これは PVC,エ ポキシ系樹脂で電極を絶緣し，金網との間隔を 0.1 イチとして電極に高電圧を印加する。そ の時金網電極に一様なコロナスパークが発生す るというものである。

日本からは慶大工の Sumida らがX 線予備 電離方式のエキシマーレーザーの特性につき発 表した。内容については正当な評価が与えられ たと思うが，X線源を含めた全体の効率につい て質間が集中した。

Rutherford のEdward らの報告は電子ビー 厶励起と injection lock の特性に関するもの であった。彼らが用いた電子ビーム装置は 1 $\mathrm{MeV}, 60 \mathrm{~ns}$ のものであるが，一寸変った所と言 えば電子ビーム空に2 重のフォイルを使ってい ることである。つまり電子銃のある真空側に Ti のpre-foil を設け, Hibachi structure を介
してレーザーチェンバー側にもう一枚の foil 設けている。出力特性としてはレーザーパルス 幅36ns，エネルギー $1.2 \mathrm{~J}$ 得ている。これに broad band. のinjection lockしたときパルス 幅60ns, エネルギー2.2Jに増大した。励起密度 $1 \mathrm{MW} / \mathrm{cm}^{3}$ において goL = 2, 飽和パラメーター $\mathrm{Is}=3 \mathrm{MW} / \mathrm{cm}^{2}$, 効率 $5.5 \%$ である。またin jection lockしたときの効率は10\%である。

エキシマーレーザーは高出力, 高効率である という点については今回の会議で実験的にも実

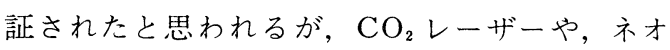
ジムガラスレーザーと違ってエネルギーを蓄積 することが出来ない。従ってピークパワーを向 上させるためにはポンピングパワーを増大させ なければならない。エキシマーレーザーのエネ ルギーを変換してピークパワーを増大する手法 に関して $2 ， 3$ の報告があったので最後にそれ らについて述べる。

その一つはLLLの Jacobs らによるラマン パルス圧縮に関する発表である。用いられたレ 一ザーはパルス幅30ns, 出力エネルギー $1 \mathrm{~J} の$ 248 nm KrFレーザーである。まず3枚のintracavity エタロンによりスペクトル幅を $0.15 \mathrm{~cm}^{-1}$ に狭めた $1 \mathrm{~mJ}$ エネルギーを再生増幅器により $150 \mathrm{~mJ}$ で増幅し, さらにunstable 共振器を もつ増幅器を injection lock しさらに1段増 幅して最終的に $1 \mathrm{~J}$ の出力エネルギーを得てい る。一方発振段から出たストーク光は 2 段の増 幅器を通る過程で逆方向より入射されたポンプ 光により増幅されると共にパルス幅が狭まり最 終的に1. $2 \mathrm{~ns}$ のパルスが得られている。ラマン ガスは $\mathrm{CH}_{4}$ である。また効率としては70\%であ つたと報告されている。

他の方法としては M I Tより報告された XeF 励起 T m : Y LF, KrF 励起Ce：YLFレーザー に関する報告があった。いずれもスペクトル， 利得を測定している段階であるがYLFは直径 $10 \mathrm{~cm}$ ものが製作可能ということであるので将 来性があるものと思われる。

(以上) 


\section{コンファレンスレポート 5}

\section{第 6 回分子エネルギー移動に関する国際会議}

\section{土屋荘次 *

\begin{abstract}
Report on Sixth International Conference on Molecular Energy Transfer
\end{abstract} \\ Soji TSUCHIYA*}

昭和54年 7 月 16 日から 20 日までフランス南部 ロデツ市郊外のコムタール高原で開催された第 6 回分子エネルギー移動国際会議に出席する機 会を得たので報告する。

分子エネルギー移動国際会議の主な討論主題 は，第一に分子および分子集団の励起エネルギ 一が分子衝突やその他の相互作用で移動拡散す る機構についてであり, 第二にレーザー発振, 化学反応素過程などの関連分野である。この分 野の研究は, 70年代に急速に進歩した。その理 由の一つは，他の分野でもそうであるように新 しい実験手法の発展，とくにレーザーが分子の 状態の選別を可能にした点に負う所が大きい。 もう一つの理由は，化学レーザー，レーザー誘 起化学反応を典型的な例とするように光と分子 の動的なかかわり合いにもとずく新しい応用分 野の開拓が挙げられる。この会議の第 1 回は69 年ゴードン会議で出発し, 米国とヨーロッパ各 国を交互に 2 年毎に開催地として, 今年が丁度 10年目に当る。10年一昔というが，この会議の 目指す課題の発展方向に一つの節目を感じさせ たのが今度の会議であった。

この会議には，ヨーロッパからとくに佛，独 両国で約半数の 50 名の参加者があり，米国の 28 名よりもはるかに多かったのは従来に無い特徵 である。また，婦人科学者の参加が多かったの
もフランス的な特徵と言えるかも知れない。会 議は，ゴードン会議の運営方式に従い，非公式 な雲囲気を保つよう議長から要請があり, 参加 者一同大いに会議を楽しんだといえる。これは, 多分に長い食事時間とフランスワインのせいで もある。午前中に二つ, 夜一つの招待講演（各 40分）と長い討論時間（30分）がとってあり， 午后はすべてポスター発表にあてられた。少人 数の会で, 個人的に話し合う時間も十分あり, 意見交換のし易い会議運営であったと思う。

従来の分子エネルギー移動速度の測定方法の 主なものは, 光照射やその他の手段で生成させ た励起分子から発する蛍光寿命の測定であった。 この方法では，ある励起状態からどの状態へ工 ネルギーが移ったかは不明である。すなわち， その励起状態から遷移可能なすべての状態への 移動速度の総和が知れるのみである。エネルギ 一移動の始状態と終状態とを確定する研究発表 がいくつかあったことは，エネルギー移動を分 子のダイナミックスとして実験的に理解する系 口を確実なものとしたことを意味する。これら の実験では，いずれもレーザーを状態選択また は状態検出のために使用している。たとえば, Hertel (Berlin) はNa と2 原子分子線交差に おいて, レーザーで交差領域にある $\mathrm{Na} 3$ ${ }^{2} \mathrm{P}_{1 / 20 \mathrm{r} 3 / 2}$ 状態を選択し, 散乱した Na原子の速 度分析を丁寧に行って, $\mathrm{Na}$ 原子の電子エネル

* 東京大学教養学部 ( $\bar{T} 153$ 東京都目黒区駒場 3-8-1)

* College of General Education, University of Tokyo (Komaba, Meguro-ku, Tokyo 653) 
ギーが分子の振動エネルギーに転換する微分衝 突断面積を決定した。このエネルギー移動過程 のうち, $\mathrm{Na}\left(3^{2} \mathrm{P}\right)-\mathrm{H}_{2}$ 衝突についてその非経験 的ポテンシャル曲面とそれを用いたダイナミッ クスの計算の試みが同時に行われており, 実験 結果に裹付けされた $\mathrm{Na}-\mathrm{H}_{2}$ の相互作用を明ら かにしようとしている。このような研究の方法 は, 分子エネルギー移動の今後の一つの研究方 向となるであろう。状態選択の別な方法として， Dagdigian(Baltimore) は LiH の $J=1$ 状態の みを 4 重極電場でふるいわけ，衝突後の状態変 化をレーザーでモニターして $J=1 \rightarrow J^{\prime}$ への状 態から状態への過程を観測することに成功して いる。同じ線上にある研究として，Gentry

(Minneapolis) は $\mathrm{H}_{2}-\mathrm{He}, \mathrm{HD}-\mathrm{D}_{2}$ 衝突による 回転遷移の実験を紹介した。この研究は $10 \mu \mathrm{s}$ と いう短時間のパルス分子線を応用したもので, 反応器内のバックグラウンド圧力を小さくする 上で，また，パルスレーザーとの組合せなどの 点で将来性のある技術であると思う。

もう一つの研究方向は, 分子集団のエネルギ 一移動についてである。普通, 分子振動の緩和 時間は圧力に反比例する。つまり, 相互作用が 衝突する二つの分子間に局限されているからで ある。Chatelet (Villetaneuse), Gale (Palaiseau) は, 高圧で緩和時間が圧力の一次 以上の反比例関係を示し, 相互作用を 2 分子間 以上で考える必要性を示した。このことと関連 して, Ewing (Bloomington)はvan der Waals 力で結合した 2 つの分子の振動励起にともなう 前期解離 (vib-rotional predissociation) の概念を示し, 簡単な一次攝動の考え方で実験 データの解釈が可能であることを示した。この 他, マトリックス中の振動励起分子のエネルギ 一移動の実験が何件か提案された。とくにDubost（Orsay）のdiode レーザーを用いた 2 重 共鳴実験を含む高分解能分光は, マトリックス 内の場の性質について新しい情報を増やす可能 性を示している。マトリックス中の分子ダイナ ミクスは，複雑である。たとえば，Jones (Los Alamos）の Ar マトリックス中の振動励起
$\mathrm{SF}_{6}$ の拡散運動は，マトリックスを一旦昇温し， 再冷却すると停止する。このことは, 分子周辺 のマトリックスの場の微妙な性質が分子運動に

影響を与えることを示している。

強いレーザー光子場におけるエネルギー移動 をともなう衝突過程はGeorge (Rochester)ら の理論上の提案の最近の新しい型の実験として 注目を浴びている。このような過程には，昔か らわかっていた輻射性衝突 (radiative collision) がある。

たとえば， $\mathrm{A}^{*}$ が準安定な㚭態，つまり，基 低状態への輻射的遷移が禁止されているとき,

$$
\mathrm{A}^{*}+\mathrm{B} \rightarrow \mathrm{A}+\mathrm{B}+\mathrm{h} \nu
$$

のように途中に中間状態 $(\mathrm{AB})$ *を経て光子を 放出する。これは, エキシマーレーザーの重要 な素過程というべきもので

$$
\mathrm{A}(i)+\mathrm{B}(i)+h \nu \rightarrow \mathrm{A}(f)+\mathrm{B}(f)
$$

と一般的に書ける。状態 $i, f$ に色々なもの があり得る。Weiner (Maryland) は，簡単な 二次攝動の考え方で, レーザー誘起ペニングイ オン化

$$
\begin{aligned}
\mathrm{Li}^{*}(2 p)+\mathrm{Li}^{*}(2 p) & \rightarrow \mathrm{Li}_{2}^{+}+\mathrm{e} \\
& \rightarrow \mathrm{Li}^{+}+\mathrm{Li}(2 s)+\mathrm{e}
\end{aligned}
$$

の衝突断面積を説明しようとした。彼の計算に よれば，断面積はレーザー光子場に比例し，ま た，エネルギー非共鳴度 $\Delta \mathrm{E}$ に反比例する。

多原子分子の多光子励起について, Ambartzumian (Moscow) が主として Os O 招待講演を行った。 $\mathrm{Os} \mathrm{O}_{4}$ の平均吸収光子数の 測定，とくに，波長の異なる2つのレーザーを 用いたときの光子数のデータより振動励起分布 状態には，'hot' と 'cold' の二つの分子集 団があることを提唱した。また, $\mathrm{O}_{\mathrm{s}} \mathrm{O}_{4}$ の $\mathrm{S}_{0}$ の 高い振動状態を経由する $S_{1}$ けい光を観測し， これが無衝突で起ることを示した。

大きい分子の分子内モード間振動エネルギー 移動に関連して Parmenter (Indiana) が，ナ フタレンの単一振電準位への励起に基くけい光 
スペクトルの測定を数10気圧で行い, エネルギ 一の再分配が10ps の桁で起ることを示した。

しかし, この実験データの解釈については, 色 々問題がありそうである。

この他, 反応素過程についても話題があった が，この会議で筆者の受けた印象では，分子の 状態をできる限り制御して，2 分子間，また， 分子集団のエネルギー移動を分子レベルで追及 しようとする研究方向が一つの中心的流れとな るように感じられた。なお，会議のプログラム を参考のため別図として付しておいた。

最後に,この会議に出席することを可能にした 吉田科学技術財団の援助に心からの感謝の意を 表する。

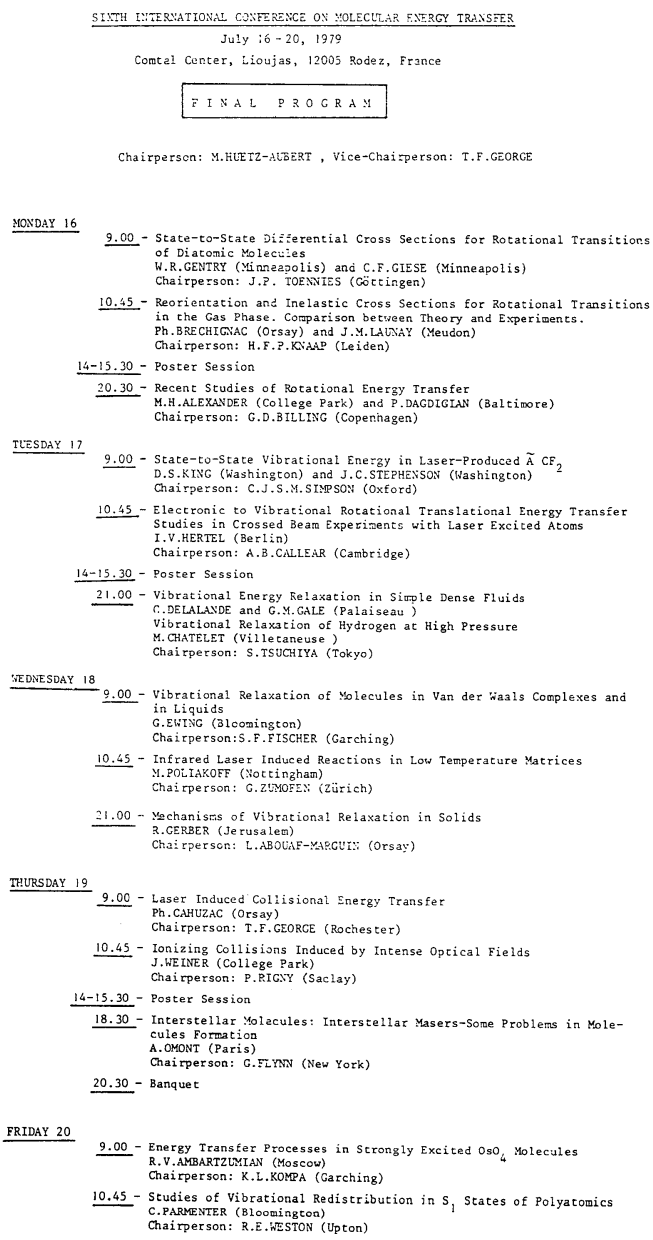

$\underline{21.00}$ - vibrational Energy Kelaxation in sirple Dense Fluids

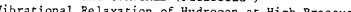
M. CHATELET (Ville tane use)
Chai rperson: S.TSUCHYA (Tokyo) 
コンファレースレポート 6

\title{
IAEA 慣性核融合技術会議の報告
}

\section{山中干代衛*}

\section{Report on IAEA Technical Committee Meeting on Advances in Inertial Confinement Systems}

\author{
Chiyoe YAMANAKA*
}

\section{1. はじめに}

国際原子力機構主催の慣性閉じ込め核融合に 関する技術会議は今回で第 5 回を数え，前回の サンフランシスコ会議についで，わが国ではじ めて開催された。場所は宝塚ホテル，日程は昭 和54年10月29日（月）から11月 1 日（木）の 4 日間, 参加者はわが国の40名を筆頭に米国12名, ソ連 3 名, 英国 2 名, フランス 2 名, カナダ 2 名, 以下オランダ, アルゼンチン，オーストラ リアが各 1 名, ユーラトム 1 名, IAEA より 1 名計66名であった。国別の代表者としてはわが 国は大阪大学レーザー核融合研究センターの筆 者, 米国エネルギー省慣性核融合局長 $\mathrm{G}, \mathrm{Can}$ avan, 英国はカラム研究所N. J. Peacock, フラ ンスはエコールポリテクのE. Fabre, カナダは 国立研究院の A. J.Alcock, ソ連はクルチヤトフ 研究所のL.I. Rudakou，ユートラムはC. Maisonnier, IAEA V.S. Vlansenkovである。

会議の, 正式名称はIAEA Technical Committee Meeting on Advances in Inertial

Confinement Systems 開会式には日本政府代 表として篠沢公平文部省学術国際局長, ほか山 村雄一大阪大学総長, 伏見康治日本学術会議会 長, 宮島龍興原子力委員からスピーチがあり,
Vlasenkov IAEA 代表が開会を宣した。ついで 各国代表により慣性閉じ込め核融合に関する現 状と将来計画に関する発表がつづいた。

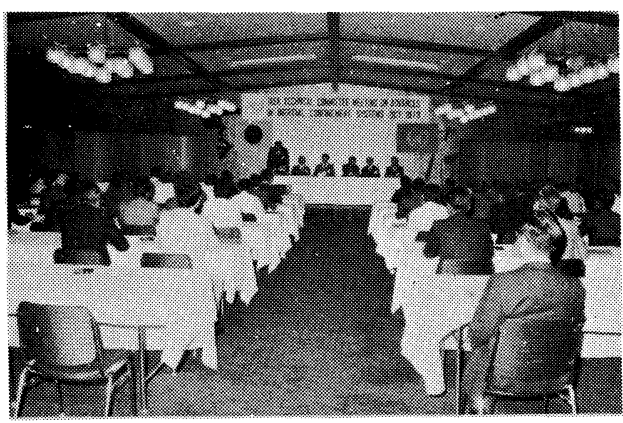

図 1 IAEA 慣性核融合技術会議開会式

今回論議された内容でとくに注目すべきこと は，慣性閉じ込め核融合がついにブレークイー ーブンを研究計画に組入れる状況に達したこと である。投大エネルギーに見合う発生エネルギ 一を実現するためには出力 $100 \mathrm{~kJ}$ 級のレーザ 一などが必要とされるが, 米国ではすでにこの クラスのレーザーの建設が始まった。ソ連では 電子ビームに重点をおいて強力なドライバーを 考えている。

わがが国もブレークイーブンを目指した「金剛 計画」を報告し，今後10年以内にこの目標に到

* 大阪大学レーザー核融合研究センター（† 565 吹田市山田上）

* Institute of Laser Engineering, Osaka University( Yamadakami, Suita, Osaka 565 ) 


\section{Fusion Development}

(Reference Budget Case)

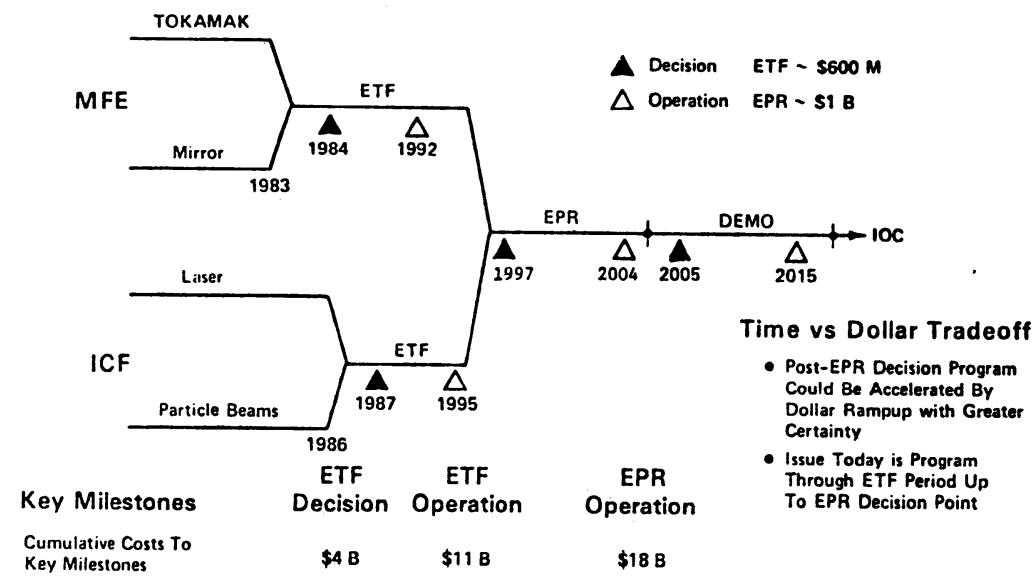

図 2 米国における核融合研究計画

達すべく努力をつづけている。困 2 は米国にお ける核融合研究戦略であって磁場閉じ込め方式 と慣性閉じ込め方式を対等にすすめていること が分かる。

レーザーを中心とするエネルギードライバー の開発に勝るとも劣らないテーマが燃料ペレッ トの設計と製作法の研究である。燃料ペレット の発生するエネルギー利得が大きければ大きい 程，慣性核融合炉の設計は容易になる。米国は 目下のところペレットに関する詳細研究を秘密 にしているが, 各国の研究進展とともにやがて 公開されるものと考えられる。わが国をはじめ 核融合平和利用に熱心な国々の一致した努力が 必要である。わが国からは新しいアイデアを盛 り达んだシミユレーションに基づくペレッ設計 が報告され注目をあびた。

第三に重要なテーマは新しい計測法を駆使し た爆縮ペレットの診断技術の確立である。レー ザーの投射により D - T ペレットは固体密度の $100 \sim 1000$ 倍に圧縮され，核融合反応の点火に 到るがこの道程をつぶさに解明するには空間的 には $\mu \mathrm{m}$, 時間的にはpsec の分解能をもつ計 測器が必要である。X 線計測を中心に新しい発 展がみられ, 圧縮時の密度 $10 〜 100 \mathrm{gr} / \mathrm{cm}^{3}$ が報 告された。
各国とも研究資金を中枢研究所に集中し強力 に研究をすすめようとしている。わが国として も各種研究機関, 企業の技術力を結果し, 研究 効率のよい方式を組織し，研究の日程表をすす めてゆくことが大切であろう。今後出力 $100 \mathrm{~kJ}$ をはるかに上まわるエネルギードライバーの建 設が心要となろうが，その時には国際協力を有 効に実施できるよう常に実力を養っておくこと が肝要である。困 3 は金剛計画の年次プランを 示したものである。

\section{2.エネルギードライバー}

慣性核融合に用いるエネルギードライバーに 関し，最近いろいろと多様化の傾向が現われた。 レーザー，電子ビーム，イオンビームなどであ る。

この中レーザーが最も技術的に進歩しており， ガラスレーザーはほぼ完成の域に達している。 ブレークイーブンに第一番に到達するのはガラ スレーザーであろう。米国カリフォルニア大学 リバモア研究所では出力 $10 \mathrm{~kJ}$ の硅酸ガラスレー ザー「シバ」をすでに核融合爆縮実験に投入し ており，本年より出力 $100 \mathrm{~kJ}$ のガラスレーザー 「ノバ」の建設に取りかかつている。完成は 1983

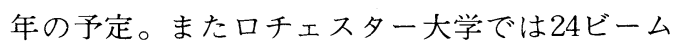




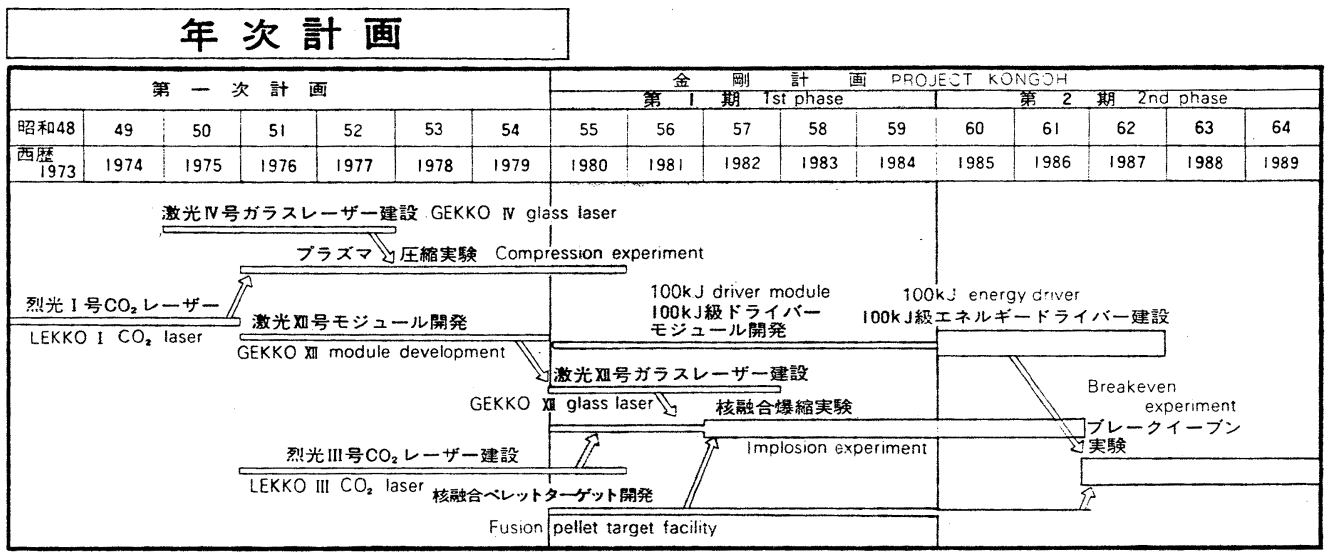

図 3 「金剛計画」レーザー核融合ブレークイーブン実証研究

ガラスレーザー「オメガ」の建設が進んでおり， 本年未には出力 $6 \mathrm{~kJ}$ の全装置が運転に入る。英 国ラザフオード研究所でも 6 ビーム，6 TW の ガラスレーザーを建設中である。大阪大学では 4 ビーム，4 TWの燐酸ガラスレーザー「激光 $\mathrm{N}$ 号」が昨年より嫁動しており, 現在 2 ビーム で $4 \mathrm{TW}$ の出力をもつ「激光X 11号モジユール」 が建設されている。このモジユールの技術を基 本にして, 12 ビーム, $20 \mathrm{~kJ}, 40 \mathrm{TW}$ の「激光XII 号」レーザーが計画されており，1982年完成予 定である。

炭酸ガスレーザーは大型化が容易であり，ま た価格や効率の面ですぐれているので今後の発 展が期待されている。カリフォルニア大学ロス アラモス科学研究所では出力 $100 \mathrm{~kJ}$ のレーザー 「アンタレス」が1984年完成予定で建設にかか つている。大阪大学では, 出力 $10 \mathrm{~kJ} 8$ ビームの 炭酸ガスレーザー「烈光VIII号」が来年度完成を めざして建設をいそいでいる。

欧州の状況は各国の思惑がからみあって複雑 である。ユーラトムの傘下ではイタリーのフラ スカッテー,ドイツのガルヒンがレーザー開発と プラズマ実験を実施しており, 前者は60年代に 「hot ice 実験」という名称で, 先駆的研究を 行つたが70年代中絶し，再び体勢をととのえつ つあり， 2 ビームの燐酸ガラスレーザーと炭酸 ガスレーザーを建設中である。後者は, 沃素レ
レーザー「アステリックス囵」を装備し, 出力 $1 \mathrm{TW}$ に及び，なお出力増強が考慮されている。 ベルギーとスエーデンでは理論的研究が行われ ている。

ユーラトムの外でフランスのリメールや，工 コールポリテクニク大, ラザフオード研究所が 独立して研究をすすめている。

粒子ビームの開発に関しては米, ソ連, 日本 が嫁動装置を保持しており，ソ連のクルチヤト フ研究所「アンガラV」モジユールと大阪の「 励電 㘯」がともにビームエネルギー $100 \mathrm{~kJ}$ 出していて，トップレベルにある。将来計画で

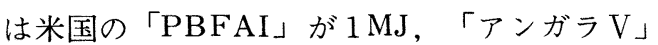
が $5 \mathrm{MJ}$ を構想している。

最近の傾向として電子ビームより陽子ビーム ビームに移行する動きが強まっている。重イオ ンビームに関しては加速器研究所を中心に計画 が論議されている。

\section{3，慣性核融合実験}

エネルギードライバー, ペレット技術, 診断 技術の三本柱の支えで慣性核融合実験が遂行さ れる。レーザーをドライバーにした研究が現在 その主流をなしている。研究の動向としては70 年代は主としてレーザー光の吸収が取り上げら れ，ほぼその機構は明らかにされたといえよう。 80年を迎えようとして今やペレット圧縮の研究 
が開発され, 比較的短パルス, 高イラディアン スのレーザーを用い, エクスプローデングモー ド(衡撃) の圧縮が研究された。この方法では 圧縮密度はあまり期待されないが, 高温の実現 が容易で, DT 反応により $3 \times 10^{13}, \mathrm{D}-\mathrm{D}$ で $10^{7}$ 内外の核融合中性子を検出している。

最近, レーザーの波長による比例則が研究対 象になつている。中でも電子の高温度成分の振 舞はペレット圧縮に関し重要な因子である。圧 縮前のプリヒートを左右するからで, レーザー 強度を $\mathrm{I}$, 波長を入とすると電子温度 $\mathrm{T}_{\mathrm{hot}}$ は $\mathrm{T}_{\mathrm{hot}} \sim\left(\mathrm{I} \lambda^{2}\right)^{\alpha}$ となり, 実験データーでは 0.3 $<\alpha<0.5$ の中に収まっている。

レーザーの出力が増加するにつれ, また燃料 ペレットのまわりに低原子番号のプラスチック 層を設定し，アブレーションが強く発生するよ うに実験条件を設定するとペレット外周がレー ザーで加熱され，アブレーションプラズマが噴 出し, そのロケット反作用で中心部の燃料が強 く圧縮される。この時比較的ゆっくりした圧縮 が行われるのでレーザー光がブリルアン散乱を うける可能性があり, その成長率の波長則が問 題となる。波長が短い程有利と考えられ, 短波 長レーザーの実験データーが盛に報告された。
爆縮の効率も当然レーザー波長別が研究の対 象になる。これにはペレットのプリヒートが強 く関係するので, 熱流の特性について詳しい実 験と物理モデルが必要である。今後これらの領 域が物理的興味の中心になろう。現在ペレット は10〜 $100 \mathrm{~g} / \mathrm{cm}^{3}$ の密度まで圧縮されている。

\section{4.おわりに}

第 5 回 IAEA 慣性核融合技術会議は文部省当 局の御協力により大阪大学がお世話して無事開 催することができた。ソ連, 米国について今度 はわが国に全世界から関係者の参加があり，4 日間の討議を通じ，わが国の研究現状を海外に つぶさに理解させ，かつわが国の若手研究者に 世界の状況を直接見聞させる機会を得たことは 今後の研究推進に大きな力になるものと確信し ている。

なお次回は慣性核融合炉の概念設計を中心に, 研究進展の討議が行われる予定である。開催場 所その他に関しては来年 1 月の IFRCで決定さ れることになろう。

最後に本会議開催に当たり御配虑頂いた政府 当局および関係方面に厚く感謝申し上げる次第, である。 